\title{
MATURITY-BASED MAPPING OF TECHNOLOGY AND METHOD INNOVATION IN OFF-SITE CONSTRUCTION: CONCEPTUAL FRAMEWORKS
}

\author{
SUBMITTED: February 2021 \\ REVISED: May 2021 \\ PUBLISHED: July 2021 \\ EDITOR: Esther Obonyo \\ DOI: $10.36680 /$ j.itcon.2021.021
}

\author{
Alaeldin Suliman, Research Associate, \\ Off-Site Construction Research Centre (ORCR), University of New Brunswick (UNB); \\ A.suliman@unb.ca \\ Jeff Rankin, Professor and Research Chair, \\ Department of Civil engineering, University of New Brunswick (UNB); \\ Rankin@unb.ca
}

SUMMARY: The construction industry has been associated with inefficiencies. In contrast, Off-Site Construction (OSC) is a modern method of construction that has demonstrated significant improvements over conventional onsite methods. Despite that, OSC represents a tiny portion of the construction industry with a limited rate of diffusion and acceptance. One reason for that is associated with the lack or immaturity of OSC-related research and innovation benchmarking. This benchmarking helps in expanding OSC implementation as a component in driving and directing OSC research as well as roadmapping and measuring the innovation advancements. Hence, this study was intended to contribute to the OSC benchmarking by mapping innovation that paves the road towards building a strategic research and innovation roadmap in OSC. Among different innovation types, this study is limited to two types: technology-oriented and OSC method-oriented innovation. Unlike the traditional roadmaps in the literature, the envisioned roadmap design for OSC innovation in this study is based on maturity modelling. This design includes four components: framework, maturity scales, benchmarks, and targets. However, the focus of the current stage is on the developing the mapping components (framework and maturity scales). Consequently, two sets of frameworks and maturity models were developed to realize the two identified innovation types in OSC. The applicability of these frameworks and scales was demonstrated through hypothetical examples and a case study that is limited to technology-oriented research in the Canadian context. Accordingly, the subsequent case study scope embraces the last three research community meetings (2015-2019) relevant to our study in the indicated context. Based on this case study, the framework was found easy to understand, simple to implement, scalable, applicable across different contexts, and facilitates capturing benchmarks and targets. This confirms promising benefits of the developed frameworks and their effectiveness in roadmapping OSC innovation.

KEYWORDS: Conceptual benchmarking framework, off-site construction, Innovation mapping framework, Maturity modelling, Technology-oriented innovation, Method-oriented innovation.

REFERENCE: Alaeldin Suliman, Jeff Rankin (2021). Maturity-based mapping of technology and method innovation in off-site construction: conceptual frameworks. Journal of Information Technology in Construction (ITcon), Vol. 26, pg. 381-408, DOI: 10.36680/j.itcon.2021.021

COPYRIGHT: (C) 2021 The author(s). This is an open access article distributed under the terms of the Creative Commons Attribution 4.0 International (https://creativecommons.org/licenses/by/4.0/), which permits unrestricted use, distribution, and reproduction in any medium, provided the original work is properly cited. 


\section{INTRODUCTION}

Construction is a series of integrated engineering and management processes that consume resources within a preset scope to produce a facility conforming of specific requirements. For a long-time, the construction industry has been associated with inefficiencies, which is argued to be mostly facilitated by the conventional on-site method of construction (McKinsey Global Institute, 2017). To address the on-site construction inefficiencies, Modern Methods of Construction (MMC) have been introduced as a new approach to improve efficiency.

MMC embraces a range of non-traditional methods of onsite and off-site construction techniques that provide alternatives to traditional construction approaches. Hence, $\mathrm{MMC}$ is an umbrella term that ranges from innovative techniques for laying bricks onsite to factory-built volumetric modules fully finished off-site (NHBC Foundation, 2018). The industrialized construction and manufacturing in factory environments promise a great potential in transforming construction industry and boost its efficiency.

Off-Site Construction (OSC) is an outcome of advancements in construction. It is an innovative engineering process that applies a significant portion of the operations to construction elements at off-site fabrication shops before delivery for installation on-site. These shops provide a more safe, controlled, and equipped work environment (Amin et al., 2012). The off-site construction process has become a crucial part of many construction projects because of its advantages over the traditional methods. Such advantages include improved productivity, safety, and quality, as well as reduced construction time and resource waste.

The propagation of OSC is limited. Despite the benefits, OSC represents a tiny portion of the national and international construction industry. Additionally, OSC diffusion and acceptance are still quite low in most construction sectors (Goulding et al., 2015). One reason for this is that it is still an immature area in terms of innovation benchmarking as it is the critical component in driving OSC research as well as roadmapping and measuring the OSC innovation advancements.

Innovation represents the core of knowledge-based economy. It contributes significantly to the domestic economic growth and hence the quality of life. The construction industry has been associated with low efficiencies and recognized for its conservatism. Hence, bringing innovation in construction is a challenge (Xue et al., 2014). However, construction innovation is the ideal way to improve the industry performances and reduce inefficiencies in terms of duration, spending, safety, quality, and many more.

Many definitions of innovation have been introduced in the construction literature. Tatum (1987) defined construction innovation as the first use of a technology within a construction firm. In a more general sense, innovation is anything new that is actually used (Slaughter, 1998). The successful innovation life cycle, in a simple format, ends by turning something new into something that is standard practice (Froese and Rankin, 2009). Even recently, the OECD/Eurostat (2018) defines an innovation, in the Oslo Manual, as "a new or improved product or process that differs significantly from the unit's previous products or processes and that has been made available to potential users (product) or brought into use by the unit (process)". This definition distinguishes between innovation as an outcome (an innovation) and the activities by which innovations come about (innovation activities).

From the innovation types' perspective, innovation can be defined as the consequence of the introduction of new products/technologies, processes, markets, organizational structures and new services (Davis et al., 2016). In contrast, the OECD/Eurostat (2018) aggregates innovation into two main types: product and process. In the construction context, Seaden (2001) introduced a more precise definition. He stated that innovation is the implementation of new products, processes, or management approaches to increase efficiency of an organization. In this definition, he highlighted the major innovation aspects or types (i.e., product, process, and management approach) and the innovation main goal in construction (i.e., efficiency increase). Other studies categorize innovation into two types: technical and organizational (Manley, 2008). While organizational innovation involves the utilization of businesses practices and management approaches, technical innovation involves the utilization of technical approaches of either process/method or product/technology innovation. Process innovations are improvements in construction methods (Tatum, 1987), whilst product innovation is the implementation and adoption of new products or technologies.

Roadmapping OSC innovation requires the development of a framework and identification of a reference point (i.e., benchmark) for use as a standard for comparison and measuring progresses/improvements (Ofori-Kuragu and Baiden, 2008). Conceptual mapping and benchmarking frameworks are the standard tool required to support driving and directing the research efforts effectively. This is because conceptual frameworks provide mental 
models that represent, simplify, and clarify complex real-world issues. They assist to understand and reason about the complex issues associated with qualitative topics such as innovation (Froese and Rankin, 2009), in this case OSC innovation. Criteria and guides for developing conceptual mapping frameworks are investigated in several studies. These guides, as recommended by Deros (2006), can be briefly summarized in: (1) easy to understand, (2) simple in structure; (3) generic and inexpensive to implement; (4) able to measure the current state (benchmark), and (5) support planning for implementation towards a future/desired state (roadmap).

The current research presents a conceptual framework for mapping innovation in OSC as the essential component for innovation benchmarking. This research contributes towards a larger strategic roadmap to drive and direct OSC research efforts as well as benchmark and measure the innovation advancements in OSC. The paper is organized as follows: a review of the most relevant previous work is presented in Section 2. The research scope, design and contribution are provided in Section 3. Section 4 and Section 5 demonstrate the development and applicability of the conceptual framework, respectively. Finally, Section $\mathbf{6}$ provides the research conclusions and an indication of next steps.

\section{PREVIOUS WORK}

Many roadmapping and strategic planning initiatives have been investigated in the literature to direct innovation within the construction industry. For example, previous studies that are relevant to research and roadmapping in the construction industry include: Seaden et al. (2001), Rezgui and Zarli (2002), and Kazi et al. (2007). To contain the scope, this paper excludes a comprehensive review of the previous work on roadmaps in construction innovation. However, a few of the most relevant studies within the international and North America contexts-are reviewed here.

The International Council for Research and Innovation in Building and Construction (CIB) is a worldwide network of building and construction experts who improve their performance through international co-operation and information exchange with their peers. As a part of CIB Task Group 74, Goulding and Arif (2013) introduced a framework to expand the global OSC adoption based on a set of priorities. In their framework, they conceptualized that OSC is originated from three industries: Construction, Design, and Manufacturing. Also, the OSC adoption and innovation are influenced by the advances in People, Processes, and Technologies under each of the three industries. Hence, nine areas (3 by 3 ) are resulted. Afterword, the researchers interviewed a focused group of stakeholders from a limited sample of countries to represent roughly both the developed and developing markets. The outcome of this roadmap is a set of priorities under each of the nine areas extended over short-term (0-5 years) and medium-term (6-10 years). The resulted roadmap is easy to understand and simple to implement. However, the adopted approach in the roadmap development is fairly open-ended and at a high abstraction level. The resulting outcome is an open-ended list of topics prioritized into high, medium, and low under each of the nine areas. The map lacks a benchmark for the current OSC innovation level, a structured formulation of the topics under each area/theme, and potentially some challenges in maintaining stability over time when the composition of the focused group changes or the scope of study in expanded geographically.

In the U.S., a Capital Projects Technology Roadmap (CPTR) was developed by FIATECH (2004) organization (a North American industry organization devoted to technology advancements for capital projects). This roadmap attempts to position emerging technologies into an overall vision for the construction industry (FIATECH, 2004). The CPTR proposes an integrated structure consisting of nine components that represent the vision of a future status in the construction industry. These components are organized according to the primary life-cycle phases of projects (planning, design, procurement, construction, and facility operations and maintenance) as follows: scenario-based project planning; automated design; integrated, automated procurement, and supply network, intelligent and automated construction job site; intelligent self-maintaining and repairing operational facility; realtime project and facility management, coordination, and control; new materials, methods, products and equipment; technology and knowledge-enabled workforce; lifecycle data management and information integration. As could be noted, CPTR as a roadmap framework does not provide clear phases of innovation process in construction nor support an assessment of the current level of innovation. Additionally, this roadmap groups technologies based on a single classification structure. Hence, such structures are limited as a means of understanding or supporting improvements to the process of innovation.

In Canada, a strategic roadmap study was been developed by Froese (2009) to direct construction innovation within the Canadian research and development (R\&D) context. In contrast to CPTR, this strategic roadmap incorporates several factors into a framework to extend the single classification model and mitigate its limitations. The study attempts to position the Canadian inventory of $R \& D$ projects through three $R \& D$ roadmaps as (1) the application 
areas, (2) the technology areas, and (3) the innovation areas. The roadmaps present three different perspectives that convey three largely orthogonal issues associated with the R\&D process. The underlaying foundation of these three Canadian R\&D roadmaps is the conceptual framework introduced by Froese and Rankin (2009). It represents the most recent framework developed and applied to roadmap construction innovation within the Canadian context. This framework proposes a sound and robust conceptualization of the innovation process. However, it is outdated and has some limitations. In other words, it is a high-level conceptual framework with general definitions of items; and it is limited to technology-oriented innovation modelling. Hence, our study was inspired by this framework with the intent of improving it by accounting for long-term changes/evolutions resulting from continuous research and development effort, focusing it to support driving OSC innovation, and expanding it to include the OSC methods-related innovation. Accordingly, this innovation framework will be reviewed in more details.

Froese and Rankin (2009) introduced a multi-dimensional framework intended for modelling construction innovation and supporting a more comprehensive and richer understanding of the innovation process. It consists of two three-dimensional sets of dimensions. While the first set includes application, technology, and innovation dimensions; the second set includes the organization scale, innovation objectives/drivers, and time dimensions. The second set of dimensions was not precisely defined in the original study. Consequently, they were excluded from the framework implementation in the original work. In contrast, the first set represents the primary dimensions that are precisely defined. As a result, they were used to develop the three Canadian research roadmaps of construction innovation. Therefore, further review is provided below on these three dimensions as follows:

First, Application areas dimension. This dimension classifies the field of activity within the construction industry to which the innovation is targeted. The application areas are categorized into three classes: (1) Management processes (e.g., construction management \& project management), (2) Project lifecycle processes (e.g., design, procurement, production, maintenance, etc.), and (3) Supporting processes are considered to provide underlying foundation for all activities (e.g., collaboration, sustainability, and workforce, etc.). Although these classes seem to be inclusive, the framework is a high-level conceptual model. For example, the supporting processing are vaguely defined (e.g., general modelling was defined). Furthermore, the framework is not specific as to the number of subclass processes and/or granularity levels. Additionally, these subclass processes and levels are expected to vary across different construction domains and change along technology evolutions without defined boundaries. For example, the lifecycle of an OSC project is different than the on-site construction project. For instance, OSC has prefabrication and on-site installation instead of simply on-site construction (Kamali and Hewage, 2017). Moreover, the supporting processing may be extended to include systems related to ICT (information and communication technologies) and safety.

Second, Technology areas dimension. This dimension categorizes technologies as being either computational or non-computational. This classification is very broad and outdated. For example, Cyber Physical Systems do not fit this taxonomy. These systems relate to mechanisms (i.e., non-computational technology) that are controlled or monitored by computer-based algorithms (i.e., digital computational technology). Furthermore, the noncomputational is an ambiguous class.

Third, Innovation dimension. This dimension explicitly models the various lifecycle stages that move innovations from a new idea to a new standard practice in five phases. These phases are data collection, technology development, conceptual development, production development, and application. They lack precision in their definitions in the conceptual framework. Furthermore, the phases are biased towards the lifecycle of academic research versus industry acceptance and exclude a measure of maturity levels.

In conclusion, in of all the previous works reviewed (roadmaps, benchmarking, and frameworks), none of them was dedicated to modelling innovation in OSC except for CIB-TG74 roadmap. Most of the currently available roadmaps of construction innovation are based on interviews, workshops, and life discussions among researchers and/or practitioners to look for urgent industry problems, barriers, and bottlenecks. This approach of building roadmaps is problem-oriented and does not provides insights on the innovation in the construction industry in both research and practice. Other approaches of roadmap's designs are based on a single-dimension classification structure/system. Such systems are limited as a mean of understanding or supporting improvements to the process of innovation. In addition to all of that, most of the available roadmaps are intended to drive technology innovation not method-oriented innovation. Additionally, most of the roadmaps identify the future trends and desired state without assessing the current state or indicating the present level of construction innovation. In other words, 
roadmaps or benchmarking frameworks based on capability and maturity models (CMM), that posses many advantages, were not found.

CMM are nominal scales often with a prescribed number of levels denoted by descriptive names. In such scales, each level is included in the consecutive ones. Therefore, these models provide benchmarks (the current level), highlight paths or roads (maturity gaps), and identify goals or target levels (the highest levels). Identifying the maturity gaps in CMM models helps in prioritizing different targets (Suliman et al., 2020). Hence, they support benchmarking and roadmapping by identifying maturity gaps and setting prioritized goals. Accordingly, if such models were used in roadmapping; the current state, desired state, and potential paths towards construction innovation can be more easily identified.

\section{RESEARCH MISSION}

In accordance with our research design, developing conceptual frameworks for organizational innovation is regarded as out of the scope. The study here focuses on two aspects of the technical innovation within OSC namely: (1) technology, and (2) engineering methods. While technology represents an appliance developed based on practical application of scientific principles, an engineering method is a designed way for implementing an engineering process to create a product as adopted from linguistic dictionaries (e.g., Mariam-webster.com). Accordingly, OSC innovation is defined, in this research, as new applications of new or existing technologies and/or engineering methods to achieve improvements in activities related to OSC. In general, innovation can lead and contribute to a variety of improvements. While the improvement dimensions identified for technology-oriented innovation include time, cost, quality, safety, certainty, and automation in cyber environment; the improvement dimensions of OSC engineering methods' innovation are increasing the degree of prefabrication and mechanization/robotics (i.e., automation in physical environment) in OSC projects.

Classifying and mapping OSC technical innovation (technologies and methods) is the aim of the current study. This study is intended to contribute, by methodology of developing conceptual frameworks, to a larger roadmapping study to drive and direct innovation in OSC and ultimately improve its implementation and acceptance rate.

Roadmapping as implied by the analogy to literal road maps, is a strategic visioning exercise intended to identify the current location/state, future location/state, and the path to get there. However, the most important part of roadmaps is the map itself. The designed roadmap in this research is illustrated in FIG. 1. The figure outlines the roadmap in four components as follows:

1. Map (framework): the framework that maps the applicable technologies to the different construction processes and engineering methods to the different product systems.

2. Maturity Models (scale): the scale for measuring the maturity of research and the industry acceptance of different technologies and engineering methods and processes.

3. Benchmark (current status): the reference that represents the maturity status at a specific point in time (i.e., the current time) with respect to a specific market context (e.g., Canadian context, North American context, or the international context).

4. Road (future/desired status): the identified targets based on the measured maturity gaps and the levels of industry acceptance.

For the sake of clarity, here is a more detailed description of this figure. The 5-by-5 grid in FIG. 1 represents the map itself (Framework) in our designed roadmap. This grid is the mapping framework of the application area of an innovation (either technology- or methods-oriented innovation) and its corresponding maturity level. Each column in this grid represents an example of an innovation application (Application areas). Each row in this grid represents a maturity level of a 5-level maturity scale (Maturity models). In this example, the 5-level scale is indicated in percentages of $20 \%$ intervals. After implementing this framework, while the shaded cells in each column represent the current maturity level of an innovation in a certain application area (Benchmark/current state), the remaining unshaded cells of each column indicate the maturity gap of that specific innovation area (Gap/road target). When the maturity gap is measured, the roadmap towards filling this innovation gap and moving to a better status is shaped.

Due to the absence of the first two components in the literature, the objective of this research is to address the critical part of the roadmap by developing a conceptual framework with maturity scale modelling to map the innovation in OSC. This innovation is modelled through technology-oriented and OSC engineering methodoriented conceptual frameworks. As recommended by Deros (2006), these frameworks are proposed to be easy to 
understand, simple in implementation, facilitate capturing the current state (benchmark), and help in designing the roadmap for a desired future state. CMM was identified as the most suitable approach for modelling the innovation dimension in this study. Accordingly, the objective in our study is to develop a mapping model (i.e., framework with its own maturity scales) for both technology-oriented and OSC engineering method-oriented innovation. The followed approach is to incorporate several dimensions into the mapping models to support a more comprehensive and richer realization of the technological type of innovation in OSC.

The contribution of the current study includes (1) identification of the main innovation dimensions in technology and engineering methods within the OSC context, (2) classification of technologies engineering methods applied in OSC, (3) categorization of the application areas for both technologies and OSC engineering methods, and (4) development of capability and maturity scales to measure the innovation level in both academia and industry domains. In contrast to most other roadmapping initiatives, this study by itself is not intended to address future priorities or planning, but rather to offer a foundation for future planning that has rarely been included in other roadmaps.

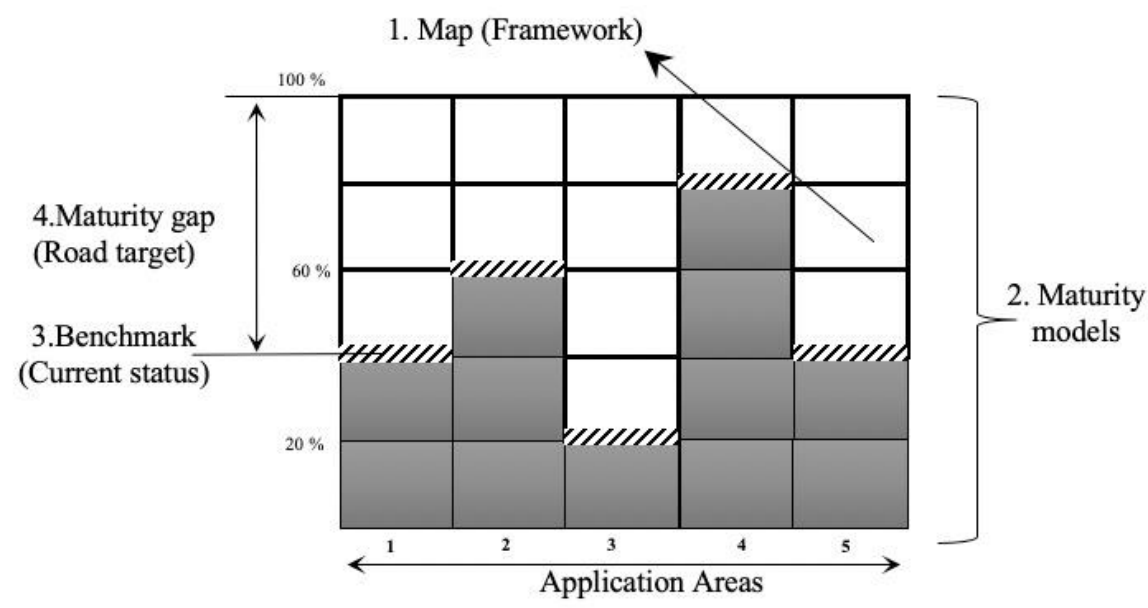

FIG. 1: The designed roadmap and its four major components.

In this research, it is worth noting that innovation is measured per project. While a research project represents the innovation sampling unit in academia, a construction project represents the innovation sampling unit in the industry. The owner's perspective has been adopted in defining the project as an innovation sampling unit to be measured in both research and industry environments.

\section{CONCEPTUAL FRAMEWORKS FOR MAPPING OSC INNOVATION}

As indicated earlier, two aspects of innovation have been identified. Accordingly, two innovation mapping models are developed for technology and OSC engineering methods. Each model is broken down into a framework and a set of maturity-based scales for the innovation dimension.

\subsection{Technology mapping model}

Technology-oriented innovation aims to achieve improvements in the application domains. Hence, to model the technology innovation in construction, the research body on innovative application of technologies in construction domain needs to be reviewed in order to identify three aspects: (1) technologies under research investigation or industry use, (2) application areas of these technologies, and (3) types of improvement achieved from the innovative applications of those technologies. Accordingly, a multi-dimensional space can be modelled, based on the bottom-up approach, to map various aspects of technology-oriented innovation in construction.

As found in the research body reviewed, there is no clear distinctions or differences available between the traditional/on-site and off-site construction projects in terms of the applied technologies. This leads to developing a technology framework that is applicable to both traditional and OSC (research and construction projects). Additionally, it was concluded that technology-oriented innovation can easily be positioned in a three-dimensional (3-D) space as conceptualized by Froese and Rankin (2009). The space includes technology, application, and innovation dimensions. As a 3-D geometric space, the first two dimensions (e.g., $\mathrm{x}, \mathrm{y}$ dimensions) define a planimetric location, while the third dimension (e.g., z dimension) defines the innovation level. At the high level, 
this conceptual model is powerful in understanding and modelling the innovation process in construction. However, the innovation dimension should also distinguish between research maturity and industry acceptance. This distinction adds more accuracy and clarity in modelling and understanding the innovation process. Furthermore, it adds more practicality (ease of use) to the model since the research and practice represent two data sources to model and measure innovation. Hence, the innovation aspect in this model has two dimensions: research maturity and industry acceptance. This resulting 4-D mapping model represents a snapshot in time within a certain scope/context (e.g., geographic location). While time changes can help identify trends, context defines boundaries in trends. Therefore, time and context dimensions have been added to the model for more complete realization of innovation aspects. Unlike the Froese and Rankin (2009) model, the innovation drivers, objectives, and the types of improvements achieved are all excluded from our model because they are either not quantifiable or of uncertain/unlimited number of options which makes it hard for maturity modelling.

In summary, six dimensions are identified to map the technology-oriented innovation as illustrated in FIG. 2. These dimensions are (1) technology areas, (2) application areas, (3) time, and (4) context, to define the technology framework. The innovation dimension is modelled in terms of maturity scales with two dimensions: (5) research maturity (academia) and (6) industry acceptance (practice). The acceptance level is selected to represent a scale of which the innovation can become a common practice. Although there is a similarity in the dimension names and purposes of the model of Froese and Rankin (2009), the applied classification and aggregation approaches are different. The next two subsections provide more details on the technology framework (Section 4.1.1) and innovation maturity scales (Section 4.1.2) respectively.

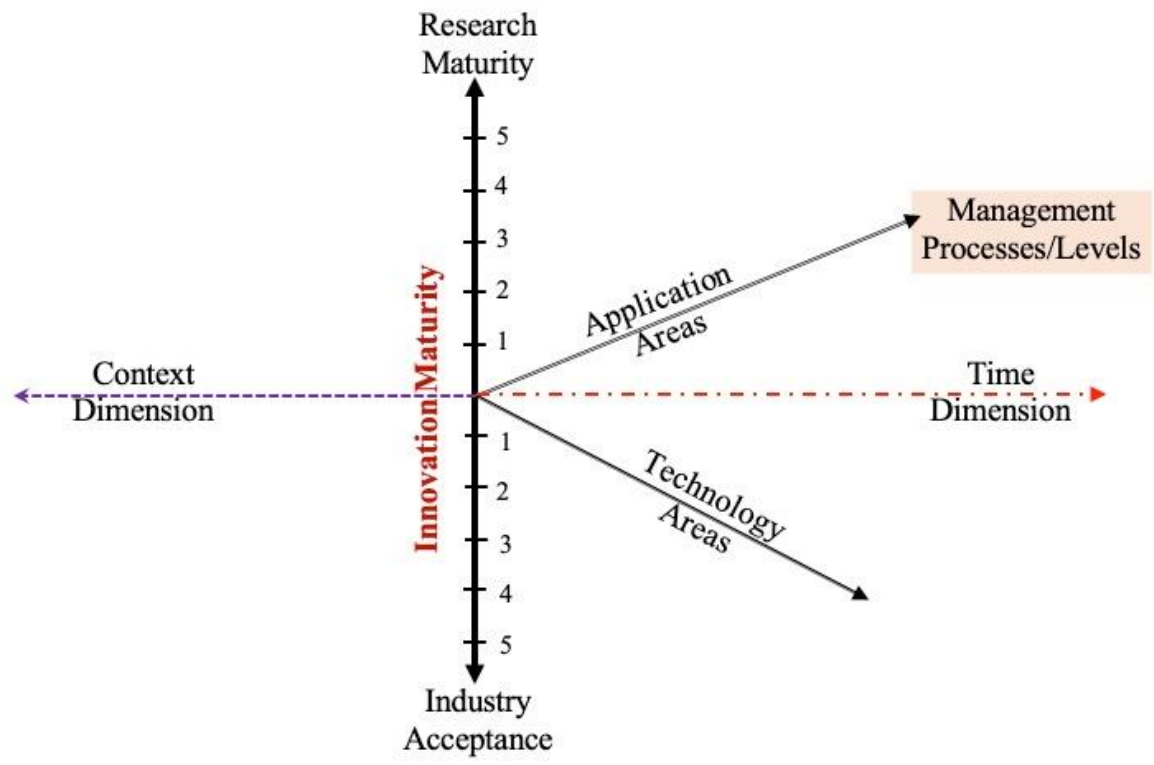

FIG. 2: The six dimensions of the technology mapping model.

\subsubsection{Technology framework}

The technology framework consists of four dimensions: technology areas, application areas, time, and context. As found in the literature, many technologies have been applied innovatively in the construction to achieve different types of improvements. While improvements can be measured in terms of time, cost, quality, safety, certainty, and automation, they cannot be uniquely classified based on any single type (i.e., a given technology may be applied for different applications and different types of improvements). Hence, a bottom-up approach was applied to classify the various types of technologies identified.

A three-theme classification of technology has been recently proposed under the umbrella of the Fourth Industrial Revolution or Industry 4.0 (4IR; Sawhney, 2018). Construction 4.0 was described as a confluence of three main, but broadly defined, themes: Industrial Production, Cyber-Physical Systems, and Digital and Computing Technologies (Bowmaster and Rankin, 2019; Sawhney, 2018). Hence, by pairing this 4IR technology classification in mind and accounting for future evolutions and changes, a bottom-up approach to categorize the various types of technologies has been applied. This approach starts by identifying individual technologies (the 
bottom level) and then group them up in areas based on a shared attribute. Accordingly, the number of technology areas have been identified.

The technology areas dimension has been developed based on five technology areas as identified applying the bottom-up approach and modifying the 4IR technology themes. These five technology areas are (1) Digital computational technologies, (2) Smart technologies, (3) Cyber-physical technologies, (4) Industry production technologies, and (5) Supporting technologies. In 4IR, digital technologies are those that live in the cyber environment, and industry production technologies are those production related technologies that operate in the physical environment. In contrast, the cyber-physical technologies are the technologies that link the two different environments, such as sensors. In our modified classification, unlike the typical digital-computational technologies, the smart technology area includes just the technologies that can self-develop decisions and take actions accordingly. This separation was made because this digital technology area may combine cyber-physical and computational technologies, such as internet of things (IoT) that includes sensors and actuators, to develop decisions and take actions accordingly. Future evolutions are expected, So, to accommodate newer technologies, the supporting technology area covers any existing or new technologies that do not fit under the other four categories. This is to account for future evolutions. The identified technologies in construction and their areas are provided in Table 1.

Table 1: The five technology areas with examples.

\begin{tabular}{|c|c|c|c|c|}
\hline $\begin{array}{l}\text { Computational } \\
\text { Technologies }\end{array}$ & $\begin{array}{c}\text { Smart } \\
\text { Technologies }\end{array}$ & $\begin{array}{l}\text { Cyber-Physical } \\
\text { Technologies }\end{array}$ & $\begin{array}{c}\text { Industry } \\
\text { production } \\
\text { Technologies }\end{array}$ & $\begin{array}{l}\text { Supporting } \\
\text { Technologies }\end{array}$ \\
\hline $\begin{array}{c}\text { Building } \\
\text { Information } \\
\text { Modeling (BIM) }\end{array}$ & $\begin{array}{l}\text { Block Chain/ } \\
\text { Smart contracts }\end{array}$ & $\begin{array}{c}\text { Mixed, Immersive, } \\
\text { Augmented or Virtual } \\
\text { Reality (MR/AR/VR) }\end{array}$ & $\begin{array}{l}\text { 3D printing/Additive } \\
\text { Manufacturing (AM) }\end{array}$ & $\begin{array}{l}\text { Information and } \\
\text { Communication } \\
\text { Technologies (ICT) }\end{array}$ \\
\hline Simulation & $\begin{array}{c}\text { Artificial } \\
\text { Intelligence }\end{array}$ & Sensors & Robotics & Symantec Web \\
\hline 4D Visualization & $\begin{array}{l}\text { Internet of } \\
\text { Things }\end{array}$ & $\begin{array}{l}\text { Identification/Localization } \\
\text { (IDRF/GPS) }\end{array}$ & & $\begin{array}{c}\text { Unmanned } \\
\text { aerial/ground vehicles } \\
\text { UAVs/GAVs }\end{array}$ \\
\hline \multirow[t]{3}{*}{ Geo-BIM } & Big Data & Computer Vison & & Mobile Devices \\
\hline & $\begin{array}{l}\text { Cloud/Fog } \\
\text { Comping }\end{array}$ & Laser Scanning & & \\
\hline & & $\begin{array}{l}\text { Ground Penetrating } \\
\text { RADAR (GPR) }\end{array}$ & & \\
\hline
\end{tabular}

The application areas dimension has been identified using a bottom-up approach for the adopted technology groups. This approach starts by identifying individual technologies and then group them up in areas based on their applications from a management perspective. In other words, the use of the reviewed technologies, and the improvement dimensions, have been listed and analysed to be classified appropriately. It was found that all technologies are applied in construction to achieve a set of improvements at five levels: Project, Process, People, Physical resources, and Product. This model has been adapted for construction projects based on the 4-P's management concept (Project, Process, People, and Product) in software engineering (Jacobson et al., 1999). The adaption was made by including the Physical resources component which represents a major area of concern in construction management unlike managing software development projects. Hence, the new model accounts for this fifth component and it is called here as the "5-P's model".

Additionally, the technologies were analysed to understand their application and purposes. An alignment was found between the purpose of the application and the basic groups of management processes: planning, execution, and monitoring. The expected benefits from applying the different technologies are as follows, (1) increased certainty in planning processes; (2) increased efficiency in the execution processes; and (3) increased effectiveness (ease and accuracy) of the monitoring processes. Therefore, the application areas of the technology groups are identified as the three management processes (planning, execution, and monitoring) of construction across the different levels (5-P's model).

Time and context are the last two dimensions in the technology framework. While trends are identified when the time dimension is included, the context dimension is to account for the scope of the framework application or scalability based on the location, market segment, management level, or government levels (e.g., maturity may vary in Canada vs. Europe vs. Asia at the organization, association, municipality, or provincial levels). 


\subsubsection{Technology maturity models}

Froese and Rankin (2009) proposed a scale of innovation as data collection, technology development, conceptual development, production development, and application. This scale is limited in precision and number of levels and does not differentiate between research and practice maturities. In contrast, the innovation dimension of technologies in our model is considered in both academia and industry to add more practicality and accuracy in modelling. While the academic research represents the innovation push, adoption in practice represents the pull. Accordingly, two measuring models are developed as presented in Table 2. This distinction permits more accurate modelling, practicality, and we presume a clearer understanding of the innovation process.

The research maturity is modelled in five levels. The definitions of these levels are provided as follows:

1. Basic research- represents the research intended to understand novel technologies and explore their application opportunities in construction domains.

2. Applied research-represents the research considered when the new technologies are being innovatively applied in construction applications.

3. Evaluation research-represents the research intended to review and assess previous studies in terms of the success, failure, costs, and benefits of the technologies applied in novel construction applications.

4. Prototype Development- represents the research that includes a development of a prototype of modified or new technology that demonstrate transferability and commercialization possibility.

5. Adoption Research-represents the research intended identify the barriers and restrictions of a technology from being transferred/adopted in the industrial practices.

The industry acceptance levels proposed in our study was made straightforward to simplifying implementation and quantification. As in Table 2, it is essentially a five-level scale based on the percentages of implementing a specific technology in a certain number of past projects within a specific context. It is worth indicating that the technology use is "continuously" throughout the project (at least one phase of its lifecycle) not a one-time trial. For example, in the last 100 construction projects, 45 projects were implemented using Building Information Modelling (BIM technology) within the Canadian context. This measure indicates that the level of BIM-adoption within Canada is $45 \%$. This percentage corresponds to level three (Adopted) in industry acceptance model that is shown in Table 2.

Table 2: Maturity models for the academic research and industry acceptance.

\begin{tabular}{cll}
\hline $\begin{array}{c}\text { Maturity } \\
\text { level }\end{array}$ & \multicolumn{1}{c}{$\begin{array}{c}\text { Research Maturity } \\
\text { (a representative sample of relevant papers/R\&D projects) }\end{array}$} & $\begin{array}{c}\text { Industry acceptance } \\
\text { (level of use in the last "x" projects) }\end{array}$ \\
\hline $\mathbf{1}$ & Basic Research (exploring/ understanding) & Limited $(\mathrm{X}<20 \%)$ \\
$\mathbf{2}$ & Applied Research (innovative applications) & Promising $(21-40 \%)$ \\
$\mathbf{3}$ & Evaluation Research (performance assessment) & Adopted $(41-60 \%)$ \\
$\mathbf{4}$ & Prototype Development (commercialization/ transferability) & Implemented $(61-80 \%)$ \\
$\mathbf{5}$ & Adoption Research (barriers \& drivers of industry acceptance) & Accepted $(\mathrm{X}>80 \%)$ \\
\hline
\end{tabular}

Hence, to implement the developed technology framework and measure the research maturity in the Canadian context for example, the research maturity model can easily be applied to a representative sample of the on-going R\&D construction research in technologies (i.e., research projects at Canadian universities or journal or conference papers published by Canadian researchers). By the same analogy, the industry acceptance of a specific technology in construction can be measured by surveying a representative sample of OSC organizations (e.g., the last " 10 " OSC projects).

Appendix A presents the developed technology mapping framework. As indicated earlier, the technology-oriented innovation includes two aspects (research maturity and industry acceptance). Each cell in the framework has upper and lower rows where the upper row is for the measured research maturity and the lower row is to document the measured industry acceptance. Each row has five space where each one is dedicated for a maturity level in a sequence from left to right. Hence, the value in each space indicates the number of collected responses (either from industry projects or academic papers) that satisfy the specific maturity level indicated by its location. For example, we may have 10 research papers about an " $\mathrm{X}$ " technology applied to a project cost estimation. Three papers are of research maturity 2, six papers are of research maturity 4, and one paper of the last maturity level. Based on this example, the upper row of the cell would be filled out as follows $[\mathbf{0}|3| \mathbf{0}|\mathbf{6}| \mathbf{1}]$. If the industry acceptance of the same technology was found to be of different levels, the same principles are applied. The received responses are 
documented in the lower row of the same cell; as an example of 17 responses, $[\mathbf{5}|7| \mathbf{0}|\mathbf{2}| \mathbf{3}]$ where five responses were considered level 1 maturity, and so long. FIG. 3 illustrates this documentation format with an example.

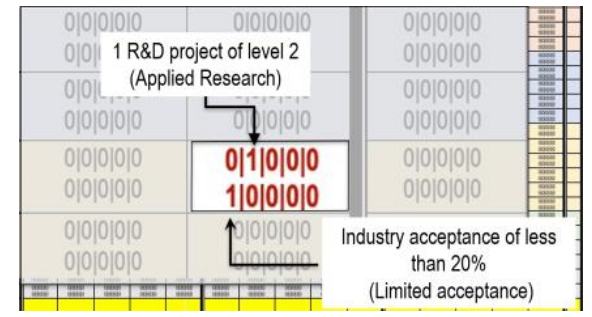

FIG. 3: Recording the levels of research maturity (upper row) and the industry acceptance (lower row).

\subsection{Method mapping model}

The engineering method-oriented innovation aims at achieving improvement in the construction process. To identify the existing methods, the literature about construction methods is reviewed. Unlike the applied technologies in construction, engineering methods for OSC are very different from the traditional on-site construction methods. Accordingly, the research body reviewed on construction methods was limited to OSC methods to align with the scope of our research. As concluded from this review, the OSC engineering methodoriented innovation aims at achieving improvements in terms of increasing the degree/portion of prefabrication (i.e., off-site) and mechanization (e.g., robotics; automation in real environments) in the construction products of the OSC projects.

Before developing a map for engineering methods, mapping dimensions need to first be identified. These dimensions are considered in the development of both the framework and maturity models of the OSC engineering methods. Based on the reviewed literature, it was concluded that method-oriented innovation can easily be positioned in a three-dimensional (3-D) space; in analogy to what was followed in the technology framework. The space includes construction product, construction process, and method innovation dimensions. As a 3-D geometric space, the first two dimensions define the planimetric location, while the third dimension defines the innovation level. At the high level, this conceptual model is powerful in understanding and modelling the innovation process in construction methods. However, since the construction products vary across different construction sectors, innovation dimension should distinguish between different construction types (e.g., buildings, infrastructure, ... etc.). Basically, construction projects can be classified inclusively into building and non-building. Hence, it is better to realize the methods' innovation aspect by two dimensions: building and non-building product maturity.

In summary, six dimensions are identified to map the method-oriented innovation as illustrated in FIG. 4.

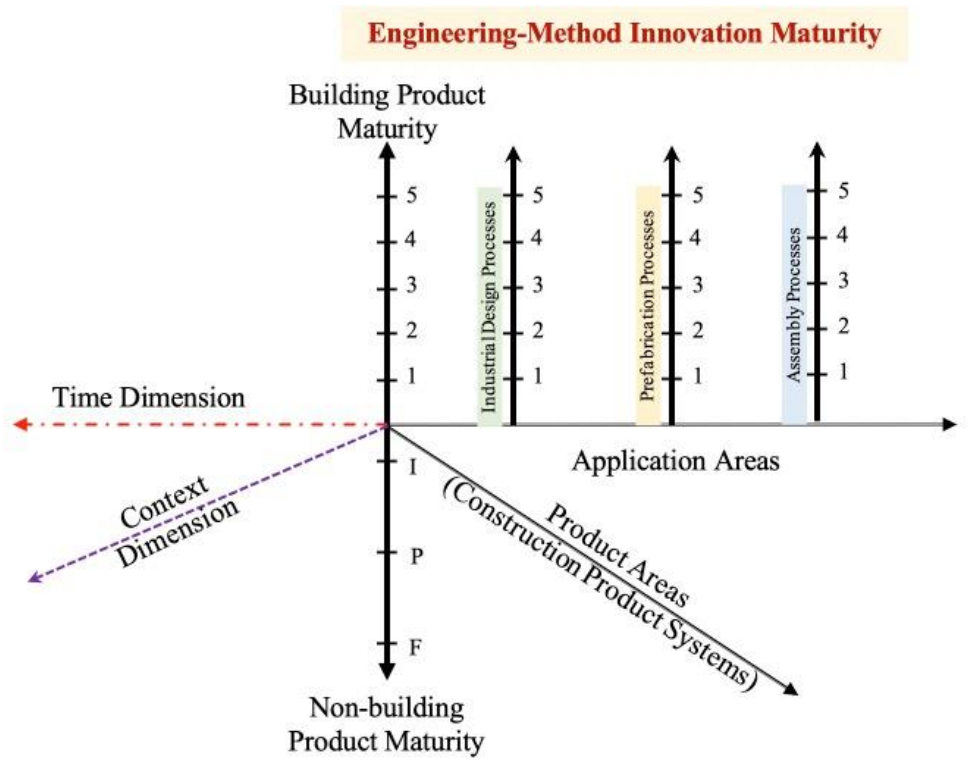

FIG. 4: The six dimensions of the engineering methods map. 
For the method framework, the dimensions are (1) product areas, (2) process areas, (3) time, and (4) context. In contrast, innovation maturity of OSC engineering methods is considered in two dimensions: construction product maturity which is realized for (5) building and (6) non-building construction; from sub-assemblies to finished products. The specific scale of the product maturity is selected to represent the maturity of the engineering method since no specific list of methods and categorization was explicitly found in the literature. As it was noticed, construction products vary across different industry sectors. Hence, a certain industry classification system needs to be adopted. Among the different industry classifications, the building construction and non-building construction taxonomy is adopted because it is simple, straightforward in understanding, and inclusive. Additionally, this taxonomy aligns with the North American Industry Classification System (NAICS) as adopted in the Canadian version. The next two subsections provide more details on the methods framework (Section 4.2.1) and innovation maturity models/scales (Section 4.2.2) respectively.

\subsubsection{OSC Engineering-method framework}

It is important to mention that no widely accepted classification system for the engineering methods in the OSC literature was found. However, good literature about OSC product classification is available. Several studies that propose different OSC classification systems were reviewed. These systems are either product-oriented or processoriented. Examples of product-oriented classifications include: (1) the type of finished product (Gibb, 2001; Gibb and Isack, 2003; Jaillon and Poon, 2009), (2) the geometrical configuration of the product (Badir et al., 2002; Thanoon et al., 2003), and (3) the location of production (Mostafa et al., 2016). A lot of inconsistencies are noticed in the various classifications. In contrast, an example of a process-oriented classification is (4) the process of manufacturing (Lawson, M., Ogden, R., Goodier, 2014).

During the review, there were several variations identified in the product-oriented classification systems. For this reason, among others, it is concluded that product-oriented systems represent most of the classifications. As a result, the classification of OSC engineering-method framework is adopted to be product oriented. This classification is inspired by a recent comprehensive study on OSC by Ayinla et al. (2019).

The product areas dimension in the engineering-method framework is selected to represent the product being constructed. This product is usually a set of integrated systems that matures from raw building materials to finished product. In other words, the construction products are simply the structural system (main system) integrated with other systems (complementary systems). The dimensions of these products evolve from zero-dimensions to 1-D, 2-D, and 3-D.

Construction element characteristics differ from one industry sector to the other. As a result, construction industry sectors relevant to our research need to be identified. Construction industry sectors are commonly classified based on the product service (Residential (i.e., homes), Institutional and Commercial (i.e., retail stores), Industrial (i.e., refineries), and Heavy and Infrastructure (i.e., ports or pipes) sectors) or based on the product structure (as building versus non-building construction). After considering the adopted abstraction of the construction elements, the classification based on the product structure was concluded to be more suitable than the classification based on the service. This classification is adopted by NAICS-Canada. Figure 5 illustrates the breakdown of construction products adopted in this study for both buildings and non-buildings.

\begin{tabular}{|c|c|c|c|c|c|}
\hline $\begin{array}{l}\text { Product Systems } \\
\text { (Building } \\
\text { Construction) }\end{array}$ & $\begin{array}{c}\text { 1. } \\
\text { Structural } \\
\text { Materials }\end{array}$ & $\begin{array}{c}2 . \\
\text { Mechanical } \\
\text { Systems }\end{array}$ & $\begin{array}{c}3 . \\
\text { Electrical } \\
\text { Systems }\end{array}$ & $\begin{array}{c}4 . \\
\text { Architect. } \\
\text { Systems }\end{array}$ & $\begin{array}{c}5 . \\
\text { Special } \\
\text { Systems }\end{array}$ \\
\hline Sub-system & $\begin{array}{l}\text { Precast } \\
\text { Steel } \\
\text { Timber } \\
\text { Polymer } \\
\text { Composite }\end{array}$ & $\begin{array}{l}\text { HVAC } \\
\text { Plumbing }\end{array}$ & $\begin{array}{l}\text { Electricity } \\
\text { Phone } \\
\text { Internet } \\
\text { TV Cable }\end{array}$ & $\begin{array}{l}\text { Interior } \\
\text { Exterior }\end{array}$ & 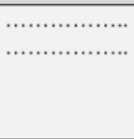 \\
\hline
\end{tabular}

(a) Building construction

\begin{tabular}{|c|c|c|c|c|c|}
\hline $\begin{array}{c}\text { Product Systems } \\
\text { (Non-building } \\
\text { Construction) }\end{array}$ & $\begin{array}{c}1 . \\
\text { Structural } \\
\text { Materials }\end{array}$ & $\begin{array}{c}2 . \\
\text { A Systems }\end{array}$ & $\begin{array}{c}3 . \\
\text { B Systems }\end{array}$ & $\begin{array}{c}4 . \\
\text { C Systems }\end{array}$ & $\begin{array}{c}5 . \\
\text { D Systems }\end{array}$ \\
\hline Sub-system & $\begin{array}{l}\text { Precast } \\
\text { Steel } \\
\text { Timber } \\
\text { Polymer } \\
\text { Composite } \\
\text { Asphalt }\end{array}$ & 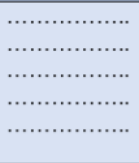 & 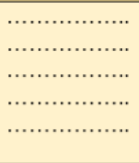 & 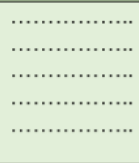 & 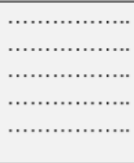 \\
\hline
\end{tabular}

(b) Non-building construction

FIG. 5: The breakdown of construction product areas for the building and non-building construction 
Process area dimensions in the engineering-method framework is selected to represent the main process phases of the value chain for the pre-installation process. Analogous to the management process groups in the technology framework, these process phases are (1) Industrial design process, (2) Manufacturing/prefabrication process, and (3) Assembly process. Under each process phase, the maturity of different phases of the construction product is included. Each phase of the indicated processes is further projected over different levels as presented in the next subsection. In this study, a distinction was made between the assembly and installation terms. While the assembly process represents the off/on-site activities required to prepare the prefab elements for installation, the installation process represents the destination (last phase) of the prefab elements on-site.

Time and context are the last two dimensions in the method framework. While trends are identified when the time dimension is included, the context dimension is to account for the boundary and scope of the framework application in terms of location, management, and/or government levels. The context dimension provides scalability advantages.

\subsubsection{OSC Engineering-method maturity models}

Innovation maturity in engineering methods and processes is proposed to be measured in four different ways; one aspect is product oriented and the remaining three aspects are process oriented. The four maturity aspects are (1) construction product, (2) industrial design process, (3) manufacturing/prefabrication process, and (4) assembly process. The main aspect is the product-oriented maturity which is applied across the different product areas and pre-installation processes.

Each of the proposed maturity scales are modified from Ayinla et al. (2019) except that of the industrial design. The industrial design maturity model is inspired from the "Design for Excellence" or DfX concept in the manufacturing industry. DfX describes design guidelines in many different areas of product development. Each design guideline addresses a specific design aspect or criteria. Therefore the " $X$ " can change for each of the design types e.g., Prefabrication/Manufacturing (DfM), Logistics/Transportability (DfL), or Assembly (DfA). DfX guidelines have proven to effectively reduce costs, time-to-market/delivery, number of assembly operations and product assembly time. The application of DfX requires manufacturing engineers and designers to work together rather than individually (Umeda et al., 2015). A description of the four proposed maturity models is provided in Table 3.

As stated above, the construction industry is classified into the building construction sector and non-building construction sector. The product maturity model presented in Table 3 is for the building construction sector where building construction products can mature up to 3-D finished/usable spaces. This is applicable regardless of the buildings intended service: residential, institutional/commercial, or industrial. However, non-building construction products have a large variety of geometries (i.e., a class of them may be linear/1-D and fully mature) and have limited number of systems (i.e., one structural material system only). Hence, for the sake of simplicity, the maturity scale of the non-building products is reduced into three maturity levels: (1) initial materials or sub-assemblies [indicated as I] (e.g., fully on-site constructed bridge); (2) partially finished product [indicated as P] (e.g., a mix of precast concrete bridge deck and on-site construction); and (3) fully finished product [indicated as F] (e.g., finished sections of the bridge road). The process phases may still be the same for both building and non-building construction.

Hence, to implement the developed method framework and measure the innovation maturity in the Canadian context for example, the product maturity models can be applied by surveying a representative set of OSC projects (from the owners' perspective) within a specific time and context (e.g., Canadian regions).

Appendix B and $\mathbf{C}$ document the engineering-method frameworks for both building and non-building OSC projects, respectively. As described in Section 4.1.2, each cell in the framework has number of spaces corresponding to the construction product maturity under each pre-installation process. While the building framework has cells with five spaces (i.e., $\mathbf{0}|\mathbf{0}| \mathbf{0}|\mathbf{0}| \mathbf{0}$ ), the cells of the non-building construction framework have three spaces (i.e., $\mathbf{0}|\mathbf{0}| \mathbf{0}$ ) to indicate $\mathbf{I}, \mathbf{P}$, and $\mathbf{F}$ maturity, respectively. This is in accordance with the maturity levels of the building and non-building products identified.

It is worth noting that the dimensional maturity of the complementary product systems (e.g., electrical, mechanical, etc. in building construction) follow the structural dimensional maturity if and only if considered in the product dimensions in industrial design. For example, an electrical system is technically considered a 1-D linear system, but if the design of a hotel pod (or any other pod/room) was constructed off-site and included all electrical systems built-in, and then "stubbed-off" for eventual connection to the main system on-site, it would be considered 3-D maturity. 
Table 3: Maturity models/scales for the OSC engineering methods.

\begin{tabular}{|c|c|c|c|c|}
\hline & Building Construction & \multicolumn{3}{|c|}{ Building and Non-building Construction products } \\
\hline \multirow[t]{4}{*}{$\begin{array}{c}\text { Maturity } \\
\text { level }\end{array}$} & Product Maturity Scale & Industrial Design Process & Prefabrication Process & $\begin{array}{c}\text { Assembly } \\
\text { Process }\end{array}$ \\
\hline & $\begin{array}{l}\text { The maturity is a scale in the number } \\
\text { of element dimensions }\end{array}$ & $\begin{array}{l}\text { The maturity is a scale in the } \\
\text { number of considered aspects in } \\
\text { the ind. design }\end{array}$ & $\begin{array}{l}\text { The maturity is a scale in the } \\
\text { degree of automation and ease of } \\
\text { manufacturing }\end{array}$ & $\begin{array}{l}\text { The maturity is a scale in the } \\
\text { degree of off-site assembly }\end{array}$ \\
\hline & $\begin{array}{l}\text { Sub-assemblies } \\
(0-D)\end{array}$ & $\begin{array}{l}\text { Design for Non } \\
\text { (NDF) }\end{array}$ & On-site/Ad-hoc & $\begin{array}{c}\text { Initial } \\
\text { on-site construction / } \\
\text { No assembly }\end{array}$ \\
\hline & $\begin{array}{l}\text { Factory manufactured items that } \\
\text { are produced offsite and certainly } \\
\text { not considered for onsite } \\
\text { production. Examples are bricks, } \\
\text { tiles, window, lighting, doors, etc. }\end{array}$ & $\begin{array}{l}\text { Just the engineering design } \\
\text { criteria. No industrial design } \\
\text { criteria were applied or } \\
\text { considered. }\end{array}$ & $\begin{array}{l}\text { The traditional on-site } \\
\text { construction methods. The } \\
\text { arrangement of processes, } \\
\text { working sites, and inventories } \\
\text { are customized based on } \\
\text { previous experiences for a } \\
\text { specific site layout. }\end{array}$ & $\begin{array}{l}\text { Traditional on-site } \\
\text { construction with no or limited } \\
\text { assembly such as sub- } \\
\text { assemblies and components. } \\
\text { This level includes also } \\
\text { prefabricated elements } \\
\text { assembled in uncontrolled } \\
\text { environment. }\end{array}$ \\
\hline & $\begin{array}{c}\text { Frame/Linear } \\
\text { (1-D) }\end{array}$ & $\begin{array}{l}\text { Design for one aspect } \\
\text { (DF1x) }\end{array}$ & Off-site Static & $\begin{array}{l}\text { Partial: Controlled Env. \& } \\
\text { On-site Construction }\end{array}$ \\
\hline & $\begin{array}{l}\text { Load-bearing structures that } \\
\text { transfer vertical and/or lateral } \\
\text { load to the foundation. Examples } \\
\text { are beams, columns, bracing, } \\
\text { etc. }\end{array}$ & $\begin{array}{l}\text { The design was optimized for } \\
\text { manufacturing/prefabrication } \\
\text { (DfM), logistics (DfL), or } \\
\text { assembly (DfA) }\end{array}$ & $\begin{array}{l}\text { A process where prefabricated } \\
\text { elements are manufactured in } \\
\text { one position, and materials, } \\
\text { services, and personnel are } \\
\text { brought to the fabrication } \\
\text { point. }\end{array}$ & $\begin{array}{l}\text { A mix of prefabricated element } \\
\text { assembly and on-site } \\
\text { construction. Assembly } \\
\text { activities may be done off-site } \\
\text { and/or off-site. }\end{array}$ \\
\hline & $\begin{array}{l}\text { Panelized } \\
\text { (2-D) }\end{array}$ & $\begin{array}{l}\text { Design for two aspects } \\
\text { (DF2x) }\end{array}$ & Off-site Linear & $\begin{array}{l}\text { Hybrid: Off- \& On- Site } \\
\text { Controlled Env. Assembly }\end{array}$ \\
\hline & $\begin{array}{l}\text { Two-dimensional building } \\
\text { components that do not enclose } \\
\text { a usable space and may include } \\
\text { several other sub-assemblies } \\
\text { that constitute part of a building. } \\
\text { Examples are wall panels, floors, } \\
\text { panels, etc. }\end{array}$ & $\begin{array}{l}\text { The design was optimized for } \\
\text { two aspects such as DfML, } \\
\text { DfLA, or DfMA. }\end{array}$ & $\begin{array}{l}\text { Production process is } \\
\text { sequential and carried out in a } \\
\text { discrete number of individual } \\
\text { stages. }\end{array}$ & $\begin{array}{l}\text { All the construction elements } \\
\text { are prefabricated in a } \\
\text { controlled environment both } \\
\text { off-site and on-site. Having } \\
\text { two assembly yards make this } \\
\text { hybrid level less mature than } \\
\text { having one assembly yard } \\
\text { either off-site or on-site. }\end{array}$ \\
\hline & $\begin{array}{l}\text { Hybrid/PODs } \\
\text { (1/2/3-D) }\end{array}$ & $\begin{array}{l}\text { Design for three aspects } \\
\text { (DF3x) }\end{array}$ & $\begin{array}{c}\text { Hybrid / } \\
\text { Semi Automated Linear }\end{array}$ & Pure On-site Assembled \\
\hline 4 & $\begin{array}{l}\text { A mix of 1,2,3 -dimensional } \\
\text { building parts that are used to } \\
\text { construct a building. Examples } \\
\text { may include off-site 1-D structural } \\
\text { elements, 2-D off-site panels for } \\
\text { walls and floors, and 3-D toilet } \\
\text { pods, and kitchen spaces either } \\
\text { usable or not usable. }\end{array}$ & $\begin{array}{l}\text { The design was optimized for } \\
\text { three aspects such as DfMLA. }\end{array}$ & $\begin{array}{l}\text { Based on the same principles } \\
\text { of conventional linear } \\
\text { production as non-automated } \\
\text { lines but tend to have more } \\
\text { dedicated stages. It may also } \\
\text { include the incorporation of } \\
\text { different manufacturing levels } \\
\text { of automation. }\end{array}$ & $\begin{array}{l}\text { The construction product is } \\
\text { fully prefabricated and most of } \\
\text { the assembly activities are } \\
\text { done on-site. }\end{array}$ \\
\hline & $\begin{array}{l}\text { Full Volumetric } \\
\text { (3-D) }\end{array}$ & $\begin{array}{l}\text { Design for four aspects } \\
\text { (DF4x) }\end{array}$ & Automated Linear & $\begin{array}{c}\text { Direct installation } \\
\text { Pure Off-site Assembled }\end{array}$ \\
\hline 5 & $\begin{array}{l}\text { Three-dimensional building parts } \\
\text { that enclose a usable space but } \\
\text { do not independently form a } \\
\text { building itself. A full building is } \\
\text { constructed from direct } \\
\text { installation of these volumetric } \\
\text { components. If these components } \\
\text { are finished with its systems, this } \\
\text { design is considered a modular } \\
\text { construction. }\end{array}$ & $\begin{array}{l}\text { The design was optimized for } \\
3+\text { aspects such as } \\
\text { installation, serviceability, or } \\
\text { sustainability. }\end{array}$ & $\begin{array}{l}\text { Linear production with } \\
\text { sequential stages that are } \\
\text { automated. }\end{array}$ & $\begin{array}{l}\text { The construction product is } \\
\text { fully prefabricated and most of } \\
\text { the assembly activities are } \\
\text { done off-site. }\end{array}$ \\
\hline
\end{tabular}




\subsection{Summary of the developed mapping frameworks and model}

As an overall summary for the mapping described in the last two subsections, FIG. 6 illustrates an overview of all developed frameworks and maturity models. As indicated in the research scope, these frameworks have been developed to map two types of innovation: (1) technology-related and (2) engineering-method-related innovation in OSC. Accordingly, two sets of six mapping dimensions have been identified. In both two sets, time and context dimensions were included to identify trends over time and to define application scope. While the left-hand side of FIG. 6 describes the technology-oriented innovation, the right-hand side depicts the engineering methods innovation in OSC.

For the technology-related innovation, the four mapping dimensions, in addition to the time and context, include (1) technology areas, (2) application areas, and the innovation dimension which is modelled in terms of maturity scales to capture two aspects: (3) research maturity (academia) and (4) industry acceptance (practice). As shown in FIG. 6, five classes of technologies (technology areas) were identified as digital, smart, cyber-physical, industrial production, and supporting technology classes. Additionally, FIG. 6 presents that the application areas are distributed in three management processes (Planning, Execution, and Monitoring process) over five management levels (Project, Process, People, Physical resources, and Product). The maturity models developed for the innovation in both research maturity and industry practice are presented at the far left of the figure.

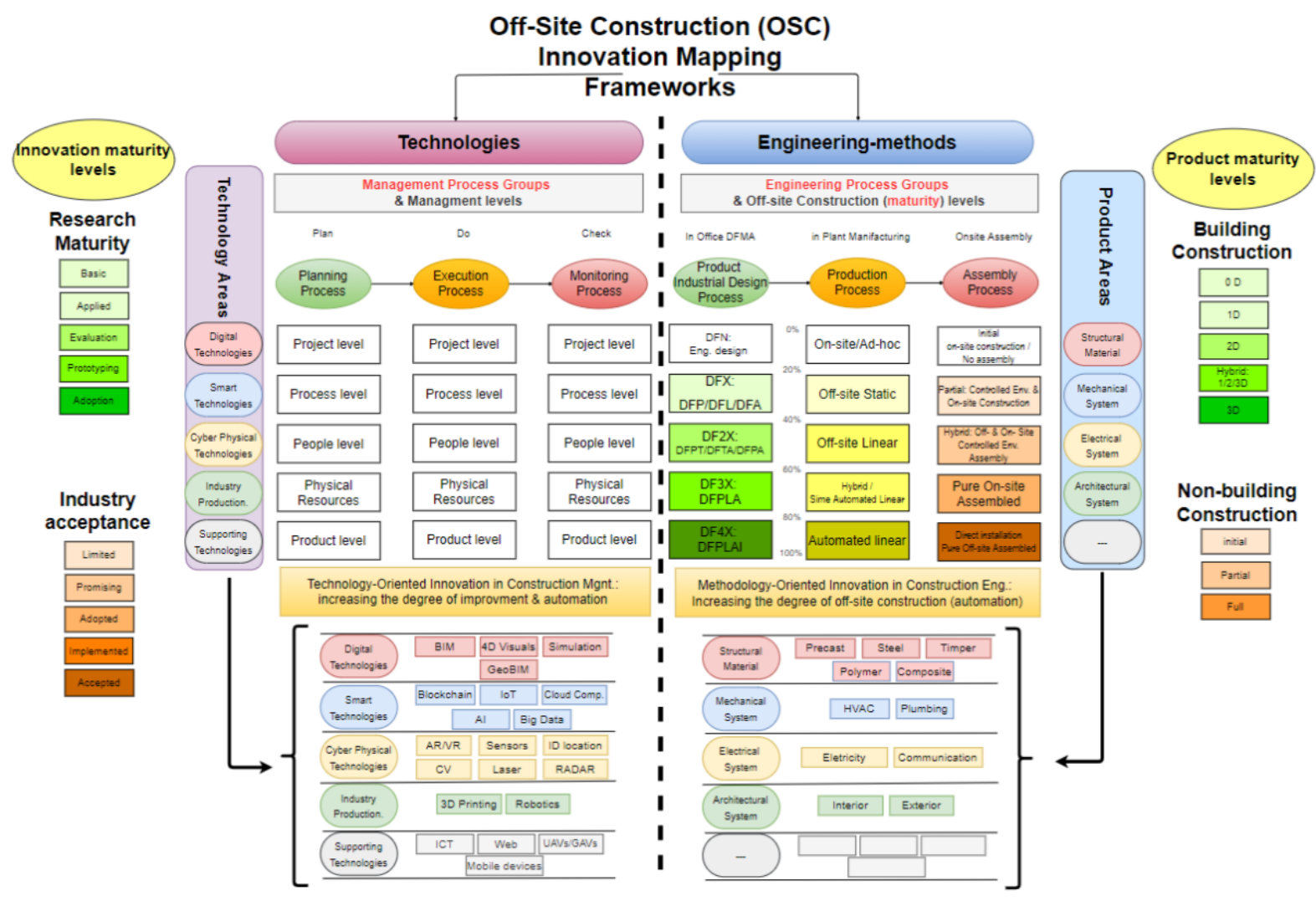

FIG. 6: an overall summary of the developed mapping Frameworks and model

For the OSC method-related innovation, the four mapping dimensions, in addition to the time and context, include (1) product areas, (2) process areas, and innovation dimension that represents maturity of OSC engineering methods. This innovation is realized in terms of two dimensions: (3) building construction product maturity and (4) non-building construction product maturity. The product production phases are represented, as in FIG. 6, by the typical pre-installation phases of OSC projects which are applicable to both construction types. These phases are (1) industrial design process, (2) manufacturing/prefabrication process, and (3) assembly process. For each production process, a five-level process maturity scale was developed as presented at the right-hand side of FIG. 6. These process maturities are applicable to both sectors of construction industry (building and non-building 
sectors). The distinction between these two construction sectors was made, in accordance with the NAICS industry classification system to accommodate the wide variety of construction products. Accordingly, two product maturity scales were developed for both construction project types. At the far right of FIG. 6, a five-level maturity scale for building construction is presented and a three-level scale for non-building construction is provided under it.

\section{APPLICABILITY DEMONSTRATION}

\subsection{Proposed implementation approach}

\subsubsection{Technology framework and maturity models}

As indicated earlier, the technology framework was designed to measure two aspects of innovation maturity: the research maturity and industry acceptance of a specific technology. To measure the research maturity based on the technology framework developed, it is suggested to review the relevant literature and/or the on-going research/R\&D projects related to the identified technologies and their application in the construction industry. The relevant literature and/or research projects are selected to define a specific time and context. For example, the current status (time dimension) of the Canadian context (context dimension). The levels of research maturity model, presented in Table 2, are applied to guide the design survey question, and assess the maturity level of the research projects (e.g., conference papers). The responses are then documented as explained in Appendix A.

To measure the industry acceptance, it is suggested to use a survey, based on the technology framework developed, with a good sample of construction companies about the adoption level of the categorized technologies in the identified application areas. The survey is used to collect responses indicating the frequency of using/applying those technologies in the last " $X$ " number of OSC projects. The level of industry acceptance model, presented in Table 2, is applied to guide the design survey questions, and measure the frequency level of a technology adoption in OSC projects. The collected responses are documented as described previously.

\subsubsection{OSC Engineering-method framework and maturity models}

As indicated, the engineering-method framework is designed to measure the innovation in OSC engineering methods/processes from four aspects: (1) the industrial design maturity (i.e., the number of the industrial design criteria applied); (2) the manufacturing process maturity (i.e., the level of automation in the physical environment); (3) the assembly process maturity (i.e., the degree of off-site assembly before installation): and (4) the construction product maturity (i.e., the degree of completeness of the product, including dimensionality). Corresponding to this, four models, as presented in Table 3, were developed to measure the maturity levels of the OSC engineering methods.

To measure the innovation maturity of OSC engineering methods, it is suggested to conduct a survey with a good sample of construction companies (e.g., statistically sufficient sample size to support $95 \%$ level of confidence in the findings across specific context), and their " $X$ " number of projects, based on the framework developed. The maturity models described in Table 3 can be used to guide the survey questions to collect responses in measuring the OSC methods maturity. The responses to be collected are then documented as explained in the relevant appendix (Appendix B).

\subsection{Hypothetical implementation example}

Examples of technology and method maturity measuring are presented in this section. The examples are intended to facilitate the understanding of the implementation of the developed maps. They are designed to cover both the technology and method frameworks and maturity models. The technology-oriented innovation assessment example is presented in

Table 4; Table 5 presents an example of the method-oriented innovation assessment in industry. The assessment results of maturity in Table 5 are related to the maturity models described in Table 3 . The hypothetical assessment outcome presented in 
Table 4 and Table 5 is documented in the relevant frameworks provided in Appendices $\mathbf{A}$ and B. The white cells with red font in these appendices are the ones that have entries based on the hypothetical assessment result. While the figures inside each cell corresponds to the number of the surveyed projects, the location of these numbers inside each cell indicates the maturity level out of the five levels of the developed maturity scales.

Table 4: Technology-oriented innovation assessment in both academia and industry.

\begin{tabular}{|c|c|c|c|c|}
\hline \multirow{2}{*}{$\begin{array}{l}\text { Innovation } \\
\text { Orientation }\end{array}$} & \multirow{2}{*}{ Aspect } & \multirow{2}{*}{ Example description } & \multicolumn{2}{|c|}{ Assessment outcome } \\
\hline & & & Framework & Maturity scale \\
\hline \multirow{2}{*}{ 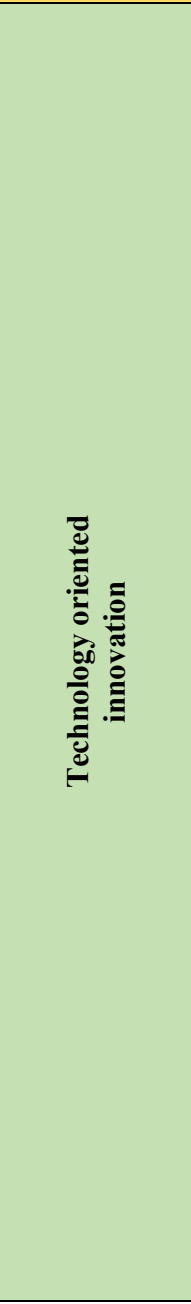 } & $\begin{array}{l}\text { Academia - } \\
\text { Research project }\end{array}$ & $\begin{array}{l}\text { Visualization technologies } \\
\text { have many promising } \\
\text { applications in developing } \\
\text { decisions and enhancing } \\
\text { insights. This research project } \\
\text { aims to enhance the design } \\
\text { experience and decision } \\
\text { making within the digital } \\
\text { environment by integrating } \\
\text { the immersive technologies } \\
\text { with existing BIM models. }\end{array}$ & $\begin{array}{l}\text { This research } \\
\text { applies immersive } \\
\text { visualization } \\
\text { technology (this is } \\
\text { part of cyber- } \\
\text { physical } \\
\text { technologies) in } \\
\text { product planning } \\
\text { (design). The } \\
\text { research focuses on } \\
\text { VR not BIM } \\
\text { technology. } \\
\text { Therefore, this } \\
\text { project is mapped } \\
\text { under the product } \\
\text { planning and virtual } \\
\text { reality technology. }\end{array}$ & $\begin{array}{l}\text { Level } 2 \text { - applied } \\
\text { This project } \\
\text { attempts to apply } \\
\text { virtual reality in } \\
\text { product design. }\end{array}$ \\
\hline & $\begin{array}{l}\text { Industry - } \\
\text { Construction project }\end{array}$ & $\begin{array}{l}\text { A construction organization } \\
\text { was contacted for survey } \\
\text { participation. The question } \\
\text { was as follows: } \\
\text { In the last } 10 \text { OSC } \\
\text { projects, how many times was } \\
\text { visualization (virtual reality) } \\
\text { technology used to enhance } \\
\text { product design process? } \\
\text { The response is } 1 \text { OSC project }\end{array}$ & $\begin{array}{l}\text { The question } \\
\text { measures the } \\
\text { frequency of using } \\
\text { virtual reality } \\
\text { technology to } \\
\text { enhance product } \\
\text { design. } \\
\text { Therefore, the } \\
\text { response should be } \\
\text { mapped under } \\
\text { product planning } \\
\text { and virtual reality } \\
\text { technology. }\end{array}$ & $\begin{array}{l}\text { Acceptance level is } \\
\text { limited (level } 1 \\
<\mathbf{2 0 \%} \\
\text { The survey } \\
\text { responder indicated } \\
\text { that the virtual } \\
\text { reality technology } \\
\text { was used for less } \\
\text { than } 20 \% \text { in the last } \\
10 \text { OSC projects. } \\
\text { Hence, the industry } \\
\text { acceptance on that } \\
\text { technology is } \\
\text { limited and it was } \\
\text { applied in one } \\
\text { project. }\end{array}$ \\
\hline
\end{tabular}

The example presented in Table 5 is a hypothetical building project intended to be constructed off-site. This project was targeted with a survey to capture a brief description of this project in terms of the produced prefab elements, the aspect considered in the industrial design, the automation in the manufacturing process, and the off-site degree of the assembly process. The response, as the project description, is provided in Table 5. While the assessment information of the structural material system represents the main system that dominates the classification of OSC projects, the assessment information of the other complementary systems (e.g., electrical) reveal more details about the OSC product. Table 6 presents the assessment outcome in a simpler format which is documented in the relevant framework (i.e., Appendix B). 
Table 5: The engineering method-oriented innovation assessment in the industry.

\begin{tabular}{|c|c|c|c|c|}
\hline \multirow{2}{*}{$\begin{array}{l}\text { Innovation } \\
\text { Orientation }\end{array}$} & \multirow{2}{*}{ Aspect } & \multirow{2}{*}{ Project brief description } & \multicolumn{2}{|c|}{ Assessment outcome } \\
\hline & & & Framework & Maturity scale \\
\hline \multirow{3}{*}{ 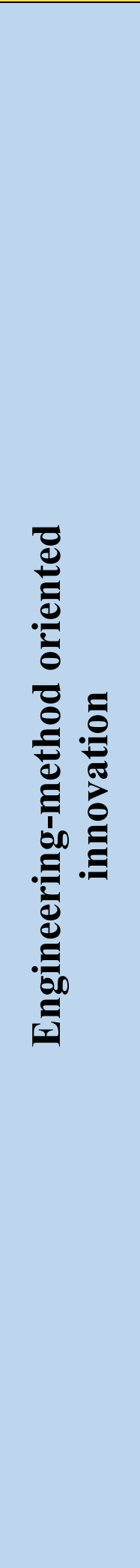 } & $\begin{array}{l}\text { Prefab product - } \\
\text { System 1: Structural } \\
\text { material system. }\end{array}$ & $\begin{array}{l}\text { Regarding the structural } \\
\text { material. This project was } \\
\text { planned to be a composite } \\
\text { (steel and timber) } \\
\text { construction building. } \\
\text { It is designed as open timber } \\
\text { panels and steel linear load } \\
\text { bearing elements. Bathroom } \\
\text { pods were sub-contracted to } \\
\text { be constructed and delivered } \\
\text { on-site for installation. The } \\
\text { electrical and mechanical } \\
\text { systems were also sub- } \\
\text { contracted. }\end{array}$ & $\begin{array}{l}\text { The project has a } \\
\text { variety of structural } \\
\text { elements. } \\
\text { 1-D elements which } \\
\text { are Load bearing } \\
\text { 2-D elements which } \\
\text { are walls. } \\
\text { 3-D elements which } \\
\text { are bathroom pods. } \\
\text { Hence, under the } \\
\text { structural material, } \\
\text { the project fits the } \\
\text { composite material } \\
\text { structural system. }\end{array}$ & $\begin{array}{l}\text { Level } 4 \text { - Hybrid } \\
\text { The structural } \\
\text { product maturity is } \\
\text { of level } 4 \text { (Hybrid) } \\
\text { since it has a } \\
\text { variety of product } \\
\text { dimensionalities. } \\
\text { The structural } \\
\text { material is } \\
\text { classified as } \\
\text { composite since the } \\
\text { building has } \\
\text { bearing steel } \\
\text { elements and } \\
\text { finished timber } \\
\text { walls. }\end{array}$ \\
\hline & $\begin{array}{l}\text { Industrial design - } \\
\text { Construction project }\end{array}$ & $\begin{array}{l}\text { The main aspect considered in } \\
\text { the industrial design is the } \\
\text { room size (the capacity) of } \\
\text { transportation trucks. Other } \\
\text { than the structural and } \\
\text { architectural systems, the } \\
\text { design did not consider the } \\
\text { industrial design the electrical } \\
\text { and mechanical systems since } \\
\text { they will be constructed on- } \\
\text { site. }\end{array}$ & $\begin{array}{l}\text { The only aspect } \\
\text { involved in the } \\
\text { industrial design of } \\
\text { the structural and } \\
\text { architectural } \\
\text { systems is the } \\
\text { transportation which } \\
\text { is part of the logistics } \\
\text { (DfL). } \\
\text { No aspects were } \\
\text { considered for the } \\
\text { electrical and } \\
\text { mechanical systems } \\
\text { since they were sub- } \\
\text { contracted to be } \\
\text { constructed on-site. }\end{array}$ & $\begin{array}{l}\text { Level } 2 \text { - DfL } \\
\text { for structural and } \\
\text { architectural } \\
\text { systems. The } \\
\text { maturity of the } \\
\text { industrial design is } \\
\text { level } 2 \text { since it has } \\
\text { only one aspect that } \\
\text { was considered. } \\
\text { Level } 1 \text { - DfN } \\
\text { for electrical and } \\
\text { mechanical } \\
\text { systems. The } \\
\text { maturity of the } \\
\text { industrial design is } \\
\text { level } 1 \text { since it was } \\
\text { constructed on site } \\
\text { (no criteria were } \\
\text { considered). }\end{array}$ \\
\hline & $\begin{array}{l}\text { Manufacturing } \\
\text { process - } \\
\text { Construction } \\
\text { company }\end{array}$ & $\begin{array}{l}\text { The manufacturing was } \\
\text { conducted by synchronizing } \\
\text { different teams and moving } \\
\text { the required resources to the } \\
\text { elements under construction. } \\
\text { These elements are then } \\
\text { moved to the storage yard } \\
\text { before loading to trucks for } \\
\text { transportation. } \\
\text { The prefabrication process } \\
\text { was conducted for the } \\
\text { structural and architectural } \\
\text { systems. However, the } \\
\text { electrical and mechanical } \\
\text { systems were considered on- } \\
\text { site. }\end{array}$ & $\begin{array}{l}\text { The manufacturing } \\
\text { process was } \\
\text { conducted as a static } \\
\text { approach. This is } \\
\text { because the resources } \\
\text { were moved to the } \\
\text { constructed elements } \\
\text { instead of the } \\
\text { opposite. } \\
\text { For the for electrical } \\
\text { and mechanical } \\
\text { systems, no off-site } \\
\text { activities were } \\
\text { considered. }\end{array}$ & $\begin{array}{l}\text { Leve } 2 \text { - Off-site } \\
\text { static } \\
\text { for structural and } \\
\text { architectural } \\
\text { systems. } \\
\text { manufacturing } \\
\text { process meats the } \\
\text { description of the } \\
\text { second maturity } \\
\text { level which is off- } \\
\text { site static. } \\
\text { Leve 1 - On- } \\
\text { site/Ad-hoc } \\
\text { for electrical and } \\
\text { mechanical } \\
\text { systems. This is } \\
\text { because they were } \\
\text { considered on-site. }\end{array}$ \\
\hline
\end{tabular}




\begin{tabular}{|c|c|c|c|c|}
\hline \multirow{3}{*}{$\begin{array}{l}\text { Innovation } \\
\text { Orientation }\end{array}$} & \multirow{2}{*}{ Aspect } & \multirow{2}{*}{ Project brief description } & \multicolumn{2}{|c|}{ Assessment outcome } \\
\hline & & & Framework & Maturity scale \\
\hline & $\begin{array}{l}\text { Assembly process - } \\
\text { Construction project }\end{array}$ & $\begin{array}{l}\text { For the structural and } \\
\text { architectural systems, while } \\
\text { an assembly yard was used for } \\
\text { partial assembly activities at } \\
\text { the prefabrication plant, most } \\
\text { of the assembly activities } \\
\text { were conducted at a yard on- } \\
\text { site. Both the off-/on-site } \\
\text { assembly yards were not } \\
\text { controlled environments. }\end{array}$ & $\begin{array}{l}\text { The assembly } \\
\text { activities of the } \\
\text { prefabricated } \\
\text { elements occurred at } \\
\text { two locations (yards): } \\
\text { off-site and off-site. } \\
\text { However, all of the } \\
\text { assembly activities } \\
\text { were conducted in } \\
\text { uncontrolled } \\
\text { environments. } \\
\text { Hence, the assembly } \\
\text { process is considered } \\
\text { initial as no assembly } \\
\text { occurred in controlled } \\
\text { environments. } \\
\text { This level applies } \\
\text { also to the electrical } \\
\text { and mechanical } \\
\text { systems }\end{array}$ & $\begin{array}{l}\text { Leve 1- Initial } \\
\text { For all systems } \\
\text { Although the } \\
\text { project was } \\
\text { considered OSC, } \\
\text { the assembly } \\
\text { process was of } \\
\text { initial level since it } \\
\text { happened in } \\
\text { uncontrolled areas. } \\
\text { This because the } \\
\text { goal of the maturity } \\
\text { model is to measure } \\
\text { degree of the off- } \\
\text { site assembly in } \\
\text { controlled } \\
\text { environments. } \\
\text { The electrical and } \\
\text { mechanical systems } \\
\text { are constructed on- } \\
\text { site thus they are } \\
\text { considered initial } \\
\text { (no-assembly) even } \\
\text { if the environment } \\
\text { (inside the } \\
\text { building) is } \\
\text { considered } \\
\text { controlled. }\end{array}$ \\
\hline
\end{tabular}

Table 6: The assessment outcome of the example presented and discussed in Table 5.

\begin{tabular}{|c|c|c|c|c|c|c|c|c|c|c|c|c|c|c|c|c|c|c|c|c|c|}
\hline \multirow{2}{*}{\multicolumn{2}{|c|}{$\begin{array}{l}\text { 음 } \\
\text { 은 } \\
\text { ํํํ }\end{array}$}} & \multicolumn{5}{|c|}{$\begin{array}{c}\text { Prefab product - } \\
\text { Structural system }\end{array}$} & \multicolumn{5}{|c|}{$\begin{array}{l}\text { Industrial design - } \\
\text { Construction project }\end{array}$} & \multicolumn{5}{|c|}{$\begin{array}{c}\text { Manufacturing } \\
\text { process - Construction } \\
\text { company }\end{array}$} & \multicolumn{5}{|c|}{$\begin{array}{l}\text { Assembly process } \\
\text { - Construction project }\end{array}$} \\
\hline & & \multicolumn{5}{|c|}{$\begin{array}{l}\text { Regarding the structural } \\
\text { material. This project was } \\
\text { planned to be composite (steel } \\
\text { and timber) construction } \\
\text { building. } \\
\text { It is designed as open timber } \\
\text { panels and steel linear load } \\
\text { bearing elements. Bathroom } \\
\text { pods were sub-contracted to be } \\
\text { constructed and delivered on- } \\
\text { site for installation. The } \\
\text { electrical and mechanical } \\
\text { systems were also sub- } \\
\text { contracted. }\end{array}$} & \multicolumn{5}{|c|}{$\begin{array}{l}\text { The main aspect considered in } \\
\text { the industrial design is the room } \\
\text { size of transportation trucks. } \\
\text { Other than the structural and } \\
\text { architectural systems, the } \\
\text { design did not include into } \\
\text { consideration the industrial } \\
\text { design of the electrical and } \\
\text { mechanical systems since they } \\
\text { will be constructed on-site. }\end{array}$} & \multicolumn{5}{|c|}{$\begin{array}{l}\text { The manufacturing was } \\
\text { conducted by synchronizing } \\
\text { different teams and moving the } \\
\text { required resources to the } \\
\text { elements under construction. } \\
\text { These elements are moved } \\
\text { then to the storage yard before } \\
\text { loading to the transportation } \\
\text { trucks. } \\
\text { The prefabrication process was } \\
\text { conducted for the structural and } \\
\text { architectural systems. However, } \\
\text { the electrical and mechanical } \\
\text { systems were considered on- } \\
\text { site. }\end{array}$} & \multicolumn{5}{|c|}{$\begin{array}{l}\text { For the structural and } \\
\text { architectural systems, while an } \\
\text { assembly yard was used for } \\
\text { partial assembly activities at } \\
\text { the prefabrication plant, most of } \\
\text { the assembly activities were } \\
\text { conducted at a yard on-site. } \\
\text { Both the off-/on-site assembly } \\
\text { yards were not controlled } \\
\text { environments. }\end{array}$} \\
\hline \multicolumn{2}{|c|}{ 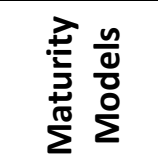 } & 웅 & 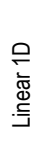 & 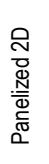 & 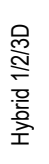 &  & 忘 & $\underset{\substack{a \\
0}}{x}$ & 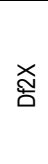 & 产 & 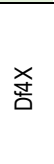 & 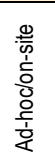 & 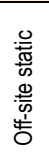 & 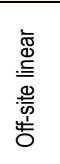 & $\begin{array}{l}\text { 은 } \\
\text { 로 }\end{array}$ & 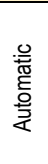 & 雱 & 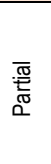 & $\begin{array}{l}\text { 은 } \\
\text { 소 }\end{array}$ & 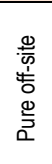 & 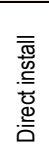 \\
\hline \multirow{4}{*}{$\begin{array}{l}\frac{y}{0} \\
0 \\
\frac{\vdots}{0} \\
\text { 전 }\end{array}$} & $\mathrm{S}$ & \multicolumn{5}{|c|}{$\begin{array}{l}\text { Composite material } \\
\quad \text { Hybrid (1/2/3D) - Level } 4\end{array}$} & & 4 & & & & & 4 & & & & 4 & & & & \\
\hline & M & \multicolumn{5}{|c|}{ 0-D - Level 1} & 1 & & & & & 1 & & & & & 1 & & & & \\
\hline & $E$ & \multicolumn{5}{|c|}{ 0-D - Level 1} & 1 & & & & & 1 & & & & & 1 & & & & \\
\hline & $A$ & \multicolumn{5}{|c|}{ Hybrid (1/2/3D) - Level 4} & & 4 & & & & & 4 & & & & 4 & & & & \\
\hline
\end{tabular}




\subsection{Case study - Technology framework}

\subsubsection{Case study scope}

In this study, the innovation mapping in OSC was limited in scope to two aspects: technology-oriented innovation and method-oriented innovation. Accordingly, CMMs where developed to model the maturity of innovation under each type. The technology-oriented innovation includes both research and industry projects, the method-oriented innovation includes both building and non-building OSC projects (industry). The case study should include the application of the developed frameworks of both technology- and method-oriented innovation. However, for demonstration purposes, the implementation of the frameworks/models developed for measuring the industryrelated maturity (i.e., technology industry acceptance and engineering methods maturities) is regarded out of the scope. Hence, in this section, we attempt to collect real data about the research projects within the Canadian context related to innovative applications of new/existing technology construction. For this purpose, a common proxy of academic papers has been used. The conferences proceedings of the Canadian Society for Civil Engineering (CSCE) are reviewed for the years: 2015, 2017, and 2019. These years represent the most recent construction speciality conferences of the CSCE.

Since it was indicated that no difference in the maturity assessment nature between OSC and traditional construction, no effort was made to select only the research projects related to technology applications in OSC domain. Hence, the assessment, in this case study, will represent only the research maturity aspect of technologyoriented innovation in construction in recent years (2015-2019) within the Canadian context (CSCE proceedings; $5^{\text {th }}, 6^{\text {th }}$, and $7^{\text {th }}$ International Construction Specialty Conferences). In accordance with the defined scope of this case study, 1,131 abstracts and/or titles of the conference papers have been reviewed. Among these papers, 109 papers $(9.6 \%)$ were found related to technology-oriented innovation in construction. A spreadsheet has been developed to document all the assessed abstracts of the construction innovation papers. Table 7 provides some details about the reviewed proceedings.

Table 7: Some details about CSCE proceedings (2015, 2017, 2019).

\begin{tabular}{|c|c|c|c|c|}
\hline CSCE Conference year/ & 2019 & 2017 & 2015 & Total \\
\hline Conference Canadian City & Laval & Vancouver & Vancouver & 10 tal \\
\hline $\begin{array}{l}\text { CSCE/CRC International Construction Specialty } \\
\text { Conference }\end{array}$ & 7th & 6th & 5th & \\
\hline $\begin{array}{l}\text { Number of papers in different areas within the } \\
\text { discipline of Civil Engineering }\end{array}$ & 456 & 470 & 205 & 1,131 \\
\hline $\begin{array}{l}\text { Number of papers related to Construction Engineering } \\
\& \text { Management (CEM) }\end{array}$ & 188 & 165 & 205 & 558 \\
\hline $\begin{array}{l}\text { Number of papers related to technology-oriented } \\
\text { innovation in CEM }\end{array}$ & 37 & 30 & 42 & 109 \\
\hline $\begin{array}{l}\text { Number construction technology innovation } \\
\text { papers from within Canadian }\end{array}$ & 20 & 16 & 31 & 67 \\
\hline
\end{tabular}

\subsubsection{Case study results}

In this case study, the technology-oriented innovation papers have been reviewed based on applying the technology framework (Section 4.1). Out of 109 papers in construction innovation submitted to construction specialty CSCE proceedings, only 67 papers were found related to technology-oriented innovation within the Canadian context. The Canadian context was identified by the affiliation of the first author, which was set to be a Canadian research institute. Thirteen Canadian institutes were found as the source of the 67 papers presented in the $5^{\text {th }}, 6^{\text {th }}, 7^{\text {th }}$ construction specialty conferences. Table 8 provides a detailed breakdown based on the numbers of the reviewed papers in these conferences (i.e., research projects). The breakdown shows the technologies investigated in construction innovation within the Canadian institutions (in the time frame 2015-2019). This table is based on pivot tables developed after applying the technology framework developed in Section 4.1.1. As graphical representations, FIG. 7 illustrates the maturity of the technology research based on the 67 papers reviewed. FIG. 8 shows the research focus of different technologies across different application areas. 
Table 8: A breakdown of the numbers of papers of technology-oriented research projects presented in the 5th, 6 th, 7th construction specialty conferences within the Canadian institutions + .

\begin{tabular}{|c|c|c|c|c|c|c|c|c|c|c|c|c|c|c|c|c|c|}
\hline \multirow{2}{*}{$\begin{array}{l} \\
\text { Canadian } \\
\text { Institutes }\end{array}$} & \multicolumn{3}{|c|}{ Conference Year } & \multirow[b]{2}{*}{ हี } & \multicolumn{4}{|c|}{ Computational Tech. } & \multicolumn{2}{|c|}{$\begin{array}{l}\text { Smart } \\
\text { Tech. }\end{array}$} & \multicolumn{5}{|c|}{ Cyber-Physical Tech. } & \multicolumn{2}{|c|}{$\begin{array}{c}\text { Support } \\
\text { Tech. }\end{array}$} \\
\hline & ฮั่ & 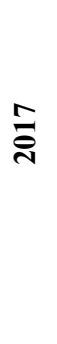 & 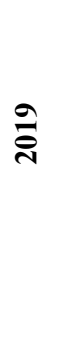 & & 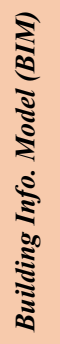 & 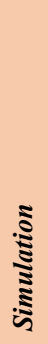 & 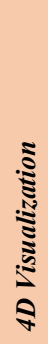 & 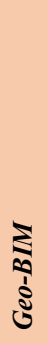 & 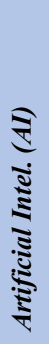 & 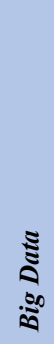 & 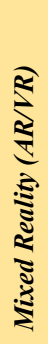 & ธัँ & 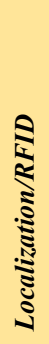 & 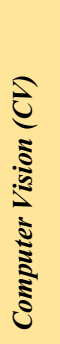 & 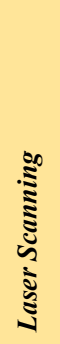 & 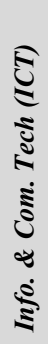 & $\underset{5}{\stackrel{5}{5}}$ \\
\hline $\begin{array}{l}\text { Concordia } \\
\quad \text { University }\end{array}$ & 7 & 3 & 5 & 15 & 1 & 4 & 1 & & 1 & 1 & & 1 & & 4 & 1 & 1 & \\
\hline $\begin{array}{l}\text { Ecole de } \\
\text { Technologie } \\
\text { Supérieure }\end{array}$ & 2 & 1 & 3 & 6 & 5 & & & & & & & & & 1 & & & \\
\hline Hydro-Québec & & & 1 & 1 & & & 1 & & & & & & & & & & \\
\hline $\begin{array}{l}\text { Lakehead } \\
\text { University } \\
\text { Southern Alberta }\end{array}$ & 1 & 1 & & 2 & & & & & & & & & & 2 & & & \\
\hline $\begin{array}{l}\text { Institute of } \\
\text { Technology }\end{array}$ & & 1 & 2 & 3 & & 1 & & & & & & & & & & & 2 \\
\hline $\begin{array}{c}\text { University of } \\
\text { Alberta }\end{array}$ & 5 & 2 & 1 & 8 & 1 & 5 & & & 1 & & & & 1 & & & & \\
\hline $\begin{array}{c}\text { University of } \\
\text { British } \\
\text { Columbia }\end{array}$ & 6 & 2 & 1 & 9 & 7 & 1 & & & & & 1 & & & & & & \\
\hline $\begin{array}{c}\text { University of } \\
\text { Calgary }\end{array}$ & 2 & & 1 & 3 & & & & & & & & & 2 & 1 & & & \\
\hline $\begin{array}{c}\text { University of New } \\
\text { Brunswick }\end{array}$ & 1 & & & 1 & & & & & & & & & & 1 & & & \\
\hline $\begin{array}{l}\text { University of } \\
\text { Ottawa }\end{array}$ & 2 & 1 & 1 & 4 & 1 & & & 3 & & & & & & & & & \\
\hline $\begin{array}{c}\text { University of } \\
\text { Toronto }\end{array}$ & & 2 & 3 & 5 & 1 & & & & 3 & & & & & & & & 1 \\
\hline $\begin{array}{c}\text { University of } \\
\text { Victoria }\end{array}$ & & 1 & & 1 & 1 & & & & & & & & & & & & \\
\hline $\begin{array}{r}\text { University of } \\
\text { Waterloo } \\
\end{array}$ & 5 & 2 & 2 & 9 & 1 & 2 & & & 1 & & & & & 2 & 2 & 1 & \\
\hline $\begin{array}{c}\text { Total \# of } \\
\text { research projects }\end{array}$ & 31 & 16 & 20 & 67 & 18 & 13 & 2 & 3 & 6 & 1 & 1 & 1 & 3 & 11 & 3 & 2 & 3 \\
\hline Sum per class & & & & & \multicolumn{4}{|c|}{36} & \multicolumn{2}{|c|}{7} & \multicolumn{5}{|c|}{19} & \multicolumn{2}{|c|}{5} \\
\hline
\end{tabular}

+ the numbers represent the number of the research projects within Canadian research institutes. 


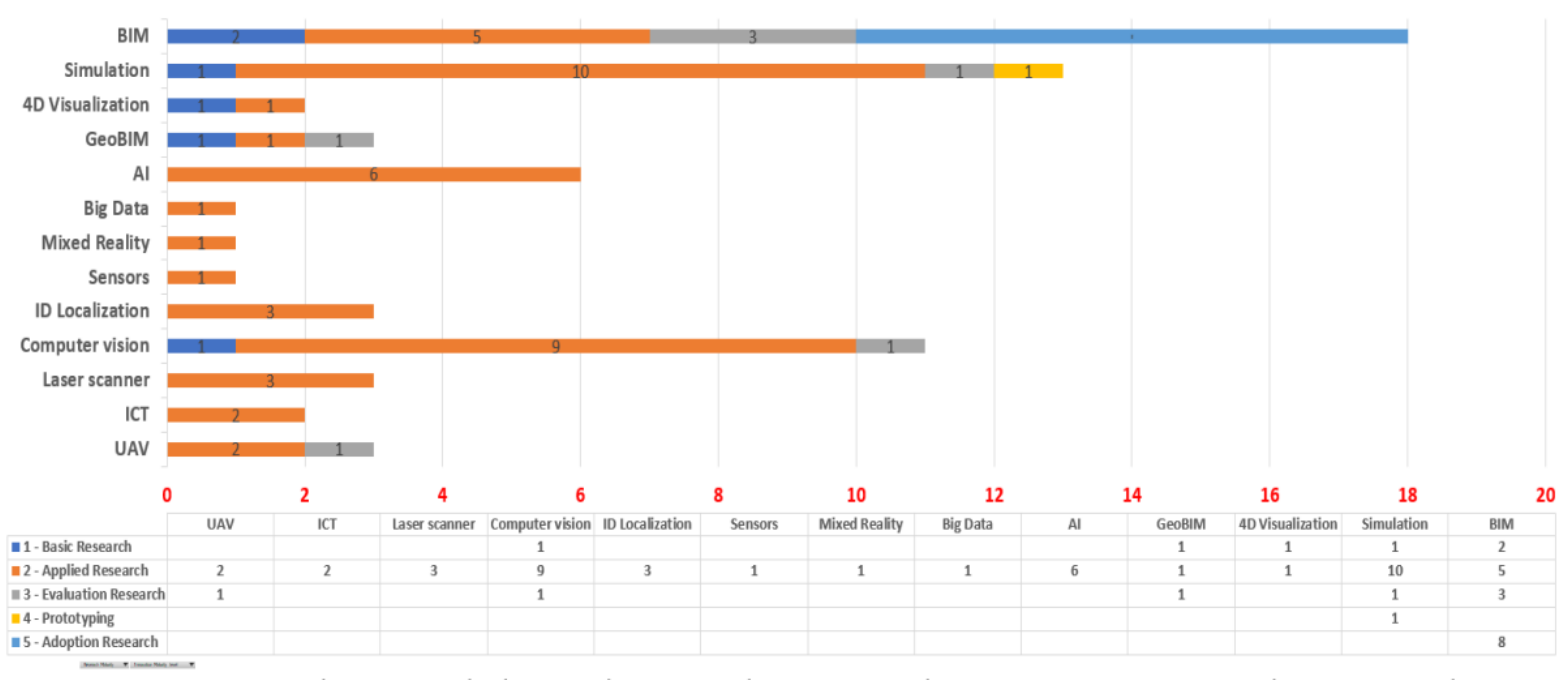

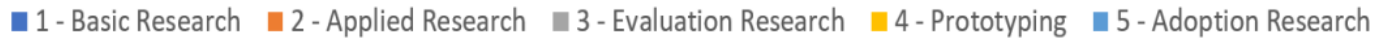

FIG. 7: The maturity of the technology research based on the 67 papers reviewed.

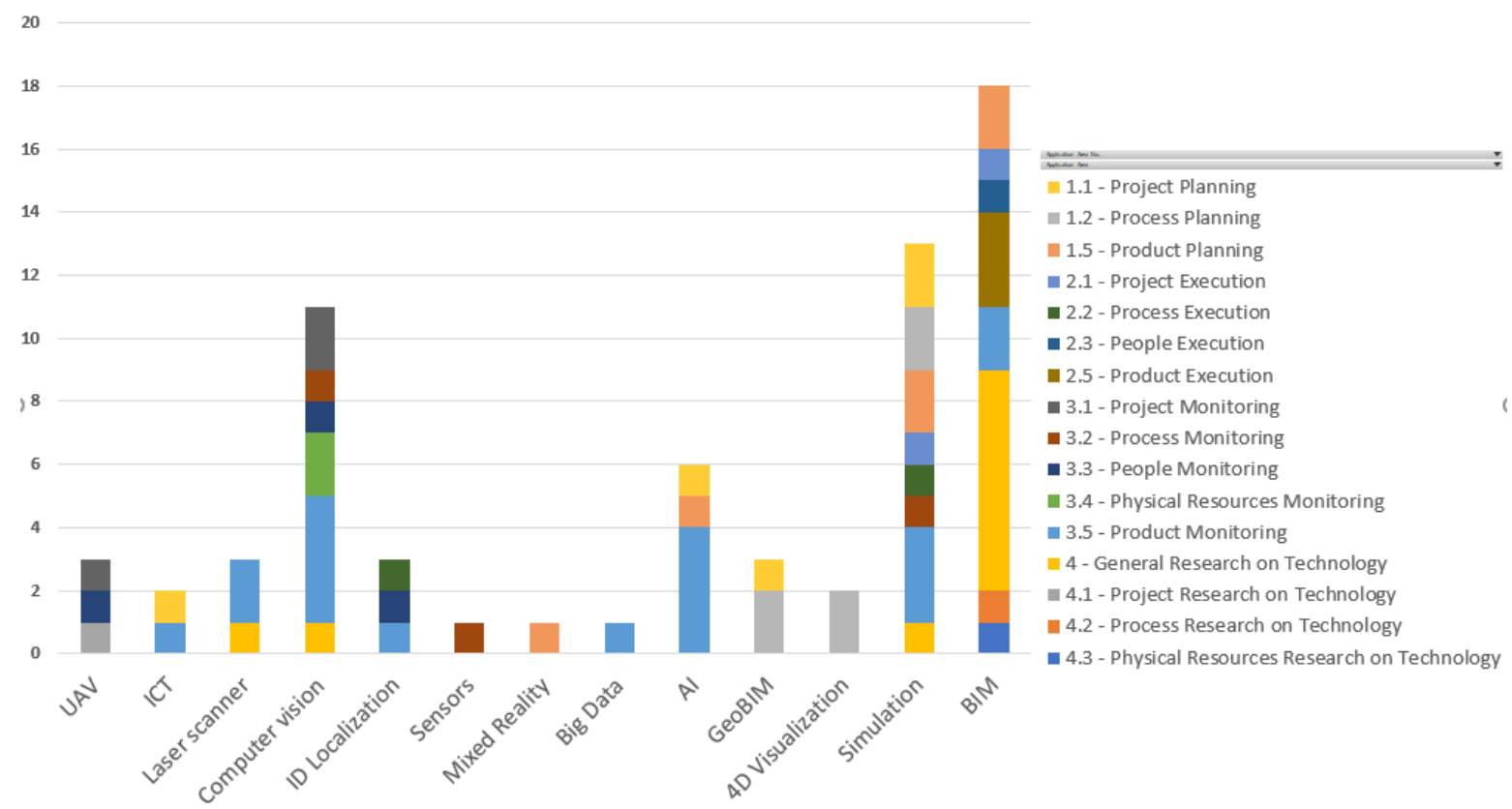

FIG. 8: The research focus of different technologies across different application areas.

\subsubsection{Case study discussion}

As presented in Table 7, the technology-oriented research projects account for almost $20 \%$ of the research related to construction engineering and management (CEM). Almost half of this percentage $(12 \%)$ is related to research projects within the Canadian context. This finding signals the significant need in increasing the research and innovation within the Canadian construction industry. A corresponding roadmap to drive and direct this innovation is definitely of critical need and importance.

As indicated in Table 8, computational and cyber-physical technology classes represent most of the research projects in Canada. This is related to the wide variety of applications of these two classes and the higher maturity levels of their research. In contrast, smart, industrial production, and supporting technology classes are quite new and less mature in research, as reflected in the small number of their research projects. Additionally, the focus of technology-oriented research within Canada is among three technologies: BIM, simulation, and computer vision. While simulation and computer vision applications represent $16.4 \%$ and $19.4 \%$ of the whole research projects 
respectively, BIM-related research itself represents approximately $27 \%$ of the research focus within Canada. The cause of this focus is influenced by the industry need, the effectiveness and success, as well as the high-level maturity of the BIM technology. In contrast, no presence was noticed for additive manufacturing and robotics in the CSCE/construction specialty conferences, as indicated in Table 8. An interpretation of this finding can be as the research of these technologies is associated with different community than CSCE society.

FIG. illustrates the research maturities of different technologies in construction. BIM technology is the only technology that was targeted with research on adoption (level 5 research maturity) to investigate the barriers of its full adoption in the construction industry. This finding aligns with what was concluded from Table 8 above. In terms of research maturity, simulation technology falls in the second place after BIM technology. Prototyping research has investigated recently in the Canadian context. This also align with the number of research projects presented in Table 8. Furthermore, FIG. shows that most of the technology-oriented innovation in construction is applied research (level 2 research maturity). The lowest maturity levels were noticed in the research related to smart technologies (AI and Big data), mixed reality, sensors, and ICT. This signals the need to further explore these technologies and their potential in construction. Simulation and computer vision technologies represents the focus of the applied research. Furthermore, evaluation research maturity (level 3) was reached for both technologies. This is also reflected in the number of their $\mathrm{R} \& \mathrm{D} /$ research projects presented in Table 8 .

Regarding the application areas of the technology-oriented innovation, FIG. illustrates the focus of research projects in terms of application areas. BIM, simulation, and computer vision covers most of the application areas with dominancy of BIM technology. However, while simulation focuses on the planning process across most management levels, the computer vision technologies are mostly applied in monitoring process across different management levels. The application areas of the rest of the available technologies in construction are quite limited and scattered across different application areas. For instance, the main application areas of the smart technologies, ICT, and sensors are process and product monitoring.

In this case study, it is worth recalling that the purpose here is to demonstrate the applicability of the technology framework. Furthermore, since this framework is applicable to both OSC and traditional construction domains as mentioned earlier, no distinction was made between these domains in the mapping and assessing of technologyrelated innovation. However, as an overall conclusion from this case study, the framework design was found easy to implement, scalable, facilitates capturing the current state (benchmarking), and helps in designing the roadmap for a desired future state. This also demonstrates and confirms the practical applicability of the developed frameworks and their effectiveness in roadmapping innovation in OSC. And more importantly, the followed methodology is replicable. This allows comparisons and identifying trends with reimplementation overtime.

\section{CONCLUSIONS}

This study was initiated to address the lack of innovation benchmarking and pave the road towards building a strategic roadmap of innovation in OSC. It attempts to develop a conceptual framework to map two types of innovation: technology-related and engineering-method-related innovation in OSC. Since OSC was characterized by limited diffusion, this study came as a response to the need and criticality of driving and directing innovation in OSC.

This research introduced a conceptual design for a maturity-based innovation roadmapping. This roadmap consists of four components: map (framework), maturity models (scales), benchmark (current state), and maturity gaps (targets for future state). The first two components were the focus of our study at this stage. Accordingly, two conceptual models were developed for mapping technology-oriented and OSC method-oriented innovation types. For this purpose, two sets of six-dimensions were identified to map both innovation types.

Regarding the technology-related innovation, the modelling dimensions include (1) technology areas, (2) application areas, (3) time, and (4) context. These four dimensions define the technology framework. In contrast, the innovation dimension is modelled in terms of maturity scales. This maturity is considered in two dimensions: (5) research maturity (academia) and (6) industry acceptance (practice). The novelty of this framework resides with introducing (a) modern classification system of technologies based on the fourth industrial revolution (IR4), (b) new categorization of application areas within construction industry, and (c) scaling systems for technologyoriented innovation in both research and practice environments.

OSC method-related innovation, is also modelled through six dimensions. The modelling dimensions are (1) product areas, (2) process areas, (3) time, and (4) context. In contrast, innovation maturity of engineering methods is considered in two dimensions: construction product maturity which is realized for (5) building and (6) non- 
building construction; from construction sub-assemblies to finished products. The distinction between construction projects was made, in accordance with the NAICS industry classification system to accommodate the wide variety of construction products. Accordingly, two product maturity scales were developed for both construction project types: five-level scale for building construction and three-level scale for non-building construction. Each of the scales were applied to the typical pre-installation phases of OSC projects which are applicable to both construction types. These phases are (1) industrial design process, (2) manufacturing/prefabrication process, and (3) assembly process. The novelty of this framework resides with introducing (a) original engineering methods classification and mapping system for OSC, (b) novel maturity scales of construction products, industrial design phases, manufacturing stages, and assembly levels, and (c) new extension of these scales over two different sectors of construction industry (building and non-building sectors).

In this research, the adopted methodology makes it possible for other future work and replicable. This allows comparisons and identifying trends with reimplementation overtime. The corresponding study outcome includes innovation assessment frameworks and maturity models for (1) technology-oriented innovation and (2) OSC engineering methods innovation for both (a) building construction and (b) non-building construction. At this stage of the research the applicability of this outcome was demonstrated through hypothetical examples and recommendations regarding the ideal implementation approach of the developed frameworks. In addition to that, the technology framework applicability was demonstrated via a real case study. For demonstration purposes, the scope of this case study was limited to the academic research (R\&D projects) related to technology-oriented innovation within the Canadian context. The framework was applied, and some significant findings and conclusions were drawn. Based on the case study, the framework implementation demonstrated to be easy to understand, simple to implement, scalable, applicable across different contexts, and facilitate capturing the current state (benchmarking). This also demonstrate the high practical applicability of the developed frameworks $/$ models and their effectiveness in roadmapping innovation in OSC.

Future steps in this research will include enhancing the developed frameworks and models by applying them in additional cases to further confirm their validity. The enhancement will include adding more details to the models to improve their clarity and robustness. This work is expected to build higher confidence in following the ideal approach of the framework implementation through online portal. The collected data via this portal will serve as alive database that support strategic roadmapping of innovation across different contexts.

\section{ACKNOWLEDGMENTS}

The authors would like to acknowledge the funding source that made this research work possible: The OSCO Construction Group. Other thanks are given to thank the anonymous reviewers as well for their helpful comments.

\section{REFERENCES}

Amin, A., Reza, A., SangHyun, L., M., A.S., and Paul, Z. (2012). Off-site construction planning using discrete event simulation. Journal of Architictural Engineering. 18, 114-122.

Ayinla, K.O., Cheung, F., and Tawil, A. (2019). Demystifying the concept of o ff site manufacturing method. Construction Innovovation. 20, 223-246.

Badir, Y.F., Kadir, M.R.A., and Hashim, A.H. (2002). Industrialized building systems construction in malaysia. Journal of Architictural Engineering. 8, 19-23.

Bowmaster, J., and Rankin, J. (2019). A research roadmap for off-site construction: automation and robotics. In Modular and Offsite Construction (MOC) Summit Proceedings, pp. 173-180.

Davis, P., Gajendran, T., Vaughan, J., and Owi, T. (2016). Assessing construction innovation: Theoretical and practical perspectives. Construction Economics and Building. 16, 104-115.

Deros, B.M., Yusof, S.M., and Salleh, A.M. (2006). A benchmarking implementation framework for automotive manufacturing SMEs. Benchmarking An International Journal. 13, 396-430.

FIATECH (2004). Capital projects technology roadmapping initiative. Austin, Texas.

Froese, T. (2009). Construction process technologies: A metaanalysis of Canadian research. Canadian journal of Civil Engineering. 36, 480-491.

Froese, T., and Rankin, J.H. (2009). Strategic roadmaps for construction innovation: Assessing the state of research. Electronic Journal Information Technology Construction. 14, 400-411.

Gibb, A.G.F. (2001). Standardization and pre-assembly-distinguishing myth from reality using case study 
research. Construction Management and Economics. 19, 307-315.

Gibb, A., and Isack, F. (2003). Re-engineering through pre-assembly: client expectations and drivers. Building Research and Information. 31, 146-160.

Goulding, J. and Arif, M. (2013), "Offsite production and manufacturing, CIB general secretariat", CIB Publication 372, CIB general Secreteiat, https://site.cibworld.nl/dl/publications/pub_372.pdf

Goulding, J.S., Pour Rahimian, F., Arif, M., and Sharp, M.D. (2015). New offsite production and business models in construction: priorities for the future research agenda. Architectural Engineering and Design Management $11,163-184$.

Jacobson, I., Booch, G., and Rumbaugh, J. (1999). The unified software development process. Addison-Wesley Longman Publishing Co., Inc., USA.

Jaillon, L., and Poon, C.S. (2009). The evolution of prefabricated residential building systems in Hong Kong: A review of the public and the private sector. Automation in Construction. 18, 239-248.

Kamali, M., and Hewage, K. (2017). Development of performance criteria for sustainability evaluation of modular versus conventional construction methods. Journal of Cleaner Production. 142, 3592-3606.

Kazi, A., Hannus, M., and Zarli, a (2007). Strategic roadmaps and implementation actions for ICT in construction.Stat-CON Consortium constituting:VTT, CSTB, and TU. From http//Cic. Vtt. Fi/Projects.

Lawson, M., Ogden, R., Goodier, C. (2014). Design in Modular Construction.CRC Press -Taylor \& Francis Group.London.

Manley, K. (2008). Against the odds: Small firms in Australia successfully introducing new technology on construction projects. Research Policy. 37, 1751-1764.

McKinsey Global Institute (2017). Reinventing construction: a route to higher productivity.

Mostafa, S., Chileshe, N., and Abdelhamid, T. (2016). Lean and agile integration within offsite construction using discrete event simulation. Construction Innovation.16(4), 483-525.

NHBC Foundation (2018). Modern methods of construction: Who's doing what?, Report published by the NHBC Foundation Research Program. https://www.nhbcfoundation.org/wp-content/uploads/2018/11/NF82.pdf

OECD/Eurostat (2018), Oslo Manual 2018: Guidelines for Collecting, Reporting and Using Data on Innovation, 4th Edition, The Measurement of Scientific, Technological and Innovation Activities, OECD Publishing, Paris/Eurostat, Luxembourg, https://doi.org/10.1787/9789264304604-en

Ofori-Kuragu, J.. ., and Baiden, B.K. (2008). A conceptual benchmarking framework for world-class performance in Ghanaian construction firms. In The Construction and Building Research Conference, COBRA2008, RICS, The mark of property professionalism worldwide, Dublin. pp. 1-19.

Rezgui, Y., and Zarli, A. (2002). Roadcon-a European strategic roadmap towards knowledge-driven sustainable construction. Proceedings of the Institution of Civil Engineers. 150(6), 24-26.

Sawhney, A. (2018). Construction 4.0-Innovation Framework for the Built Environment. From https://www.linkedin.com/pulse/construction-40innovation-framework-built-environment-anil/

Seaden, G., and Manseau, A. (2001). Public policy and construction innovation. Building Research and Information. 29, 182-196.

Seaden, G., Goulla, M., Doutriaux, J., and Nash, J. (2001). Analysis of the survey on innovation, advanced Technologies, and practices in the Construction and Related Industries, 1999. The Institute for research in Construction of the National Research Council of Canada and by the Science, Innovation, and Electronic Information Division of Statsics canada.

Slaughter, E.S. (1998). Models of construction innovation. Journal of Construction Engineering and Management. 124, 226-231.

Suliman, A., Rankin, J., and Robak, A. (2020). CSR maturity model for smart city assessment. Canadian Journal of Civil Engineering. Just-IN. https://doi.org/10.1139/cjce-2020-0077.

Tatum, C.B. (1987). Process of innovation in construction firm. Journal of Construction Engineering and Management. 113, 648-663.

Thanoon, W.A., Peng, L.W., Kadir, M.R.A., Jaafar, M.S., and Salit, M.S. (2003). The essential characteristics of industrialised building system. In International Conference on Industrialised Building Systems, pp. $283-292$.

Umeda, S., Nakano, M., Mizuyama, H., Hibino, N., Kiritsis, D., and Von Cieminski, G. (2015). Advances in Production Management Systems: Innovative Production Management Towards Sustainable Growth: IFIP 
WG 5.7 International Conference, APMS 2015, Tokyo, Japan, September 7-9, 2015, Proceedings, Part I (Springer).

Xue, X., Zhang, R., Yang, R., and Dai, J. (2014). Innovation in construction: A critical review and future research. International Journal of Innovation Science. 6, 111-125.

\section{APPENDIXES}

Below are the three innovation assessment frameworks for (1) technology innovation (Appendix A), and (2) engineering methods innovation for both (a) building construction (Appendix B) and (b) non-building construction (Appendix C).

- Appendix A: The Technology Framework for construction industry.

- Appendix B: The OSC Engineering Method Framework for Building construction sector.

- Appendix C: The OSC Engineering Method Framework for Non-Building construction sector. 


\begin{tabular}{|c|c|c|c|c|c|c|c|c|c|c|c|c|c|c|c|c|c|c|}
\hline \multirow{2}{*}{\multicolumn{2}{|c|}{$\begin{array}{c}\text { XXX Context } \\
\text { Technology-oriented } \\
\text { Innovation Framework }\end{array}$}} & \multicolumn{5}{|c|}{ Planning processes } & \multicolumn{5}{|c|}{$\begin{array}{c}\text { Execution/Control } \\
\text { processes }\end{array}$} & \multicolumn{5}{|c|}{$\begin{array}{l}\text { Monitoring processes/ } \\
\text { Future planning }\end{array}$} & \multirow{3}{*}{\multicolumn{2}{|c|}{ 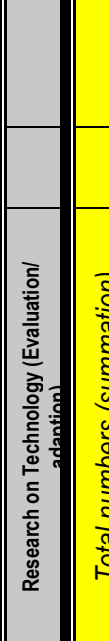 }} \\
\hline & & \multirow[b]{2}{*}{ 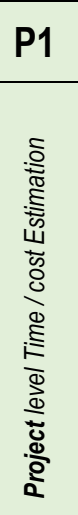 } & \multirow[b]{2}{*}{ 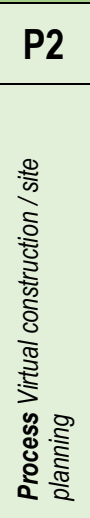 } & \multirow[b]{2}{*}{ 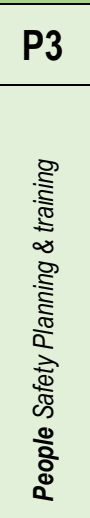 } & \multirow[b]{2}{*}{ 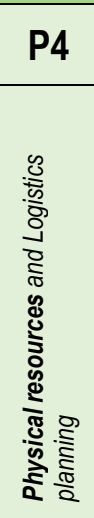 } & \multirow[b]{2}{*}{ 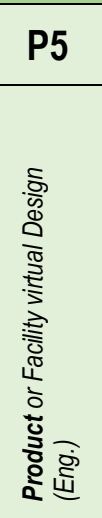 } & \multirow[b]{2}{*}{ 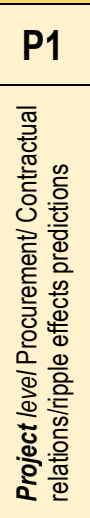 } & \multirow[b]{2}{*}{ 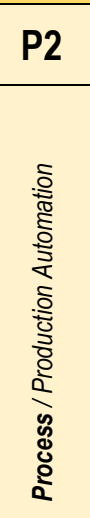 } & \multirow[b]{2}{*}{ 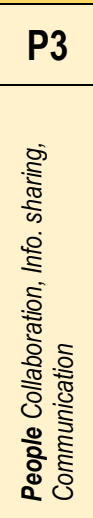 } & \multirow[b]{2}{*}{ 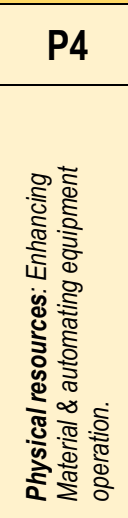 } & \multirow[b]{2}{*}{ 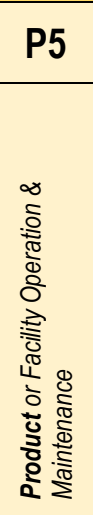 } & \multirow[b]{2}{*}{ 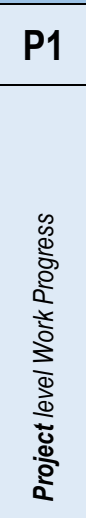 } & \multirow[b]{2}{*}{ 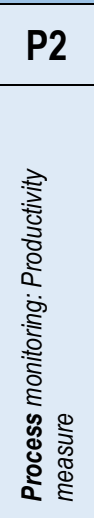 } & \multirow[b]{2}{*}{ 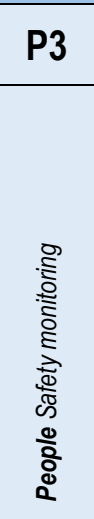 } & \multirow[b]{2}{*}{ 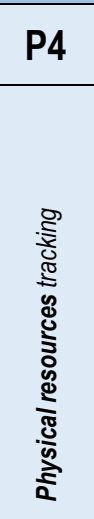 } & \multirow[b]{2}{*}{ 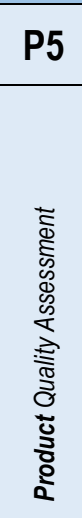 } & & \\
\hline 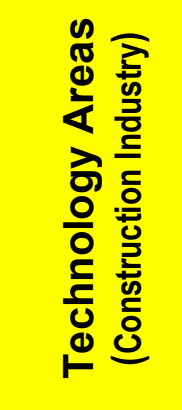 & 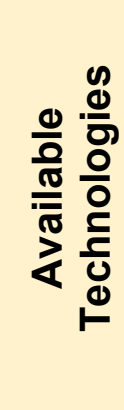 & & & & & & & & & & & & & & & & & \\
\hline \multirow{4}{*}{ 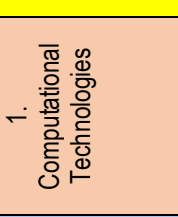 } & $B I M$ & 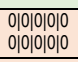 & 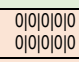 & 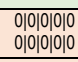 & 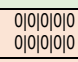 & $\begin{array}{l}0|0| 0|0| 0 \mid 10 \\
0|0| 0|0| 0 \mid 0 \\
\end{array}$ & 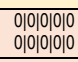 & 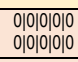 & 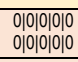 & 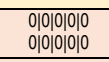 & 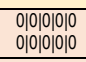 & 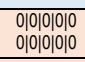 & 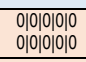 & 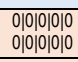 & 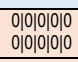 & 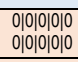 & & \\
\hline & Simulat. & $\begin{array}{l}010101010 \\
010101010\end{array}$ & 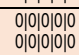 & 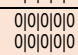 & 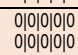 & 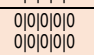 & 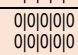 & $\begin{array}{l}0 \mid 010101010 \\
0 \mid 10101000\end{array}$ & $\begin{array}{l}0 \mid 010101010 \\
0 \mid 0101000\end{array}$ & $\begin{array}{l}0,0100100 \\
0,010000\end{array}$ & 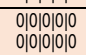 & $\begin{array}{l}0|010| 0 \mid 010 \\
0 \mid 010100\end{array}$ & 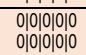 & $\begin{array}{l}0|0| 0|0| 100 \\
0|0| 0|0| 00\end{array}$ & $\begin{array}{l}0,010|0| 10 \\
0,010100\end{array}$ & $\begin{array}{l}0|0| 0|0| 100 \\
0|0| 0|0| 00\end{array}$ & & \\
\hline & 4D Vis. & $\begin{array}{l}0,10101010 \\
010101010\end{array}$ & $\begin{array}{l}01010101010 \\
010010100\end{array}$ & 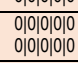 & 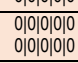 & $\begin{array}{l}01010101010 \\
010010100\end{array}$ & 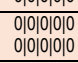 & 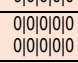 & 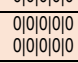 & 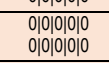 & 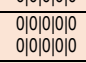 & 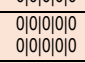 & 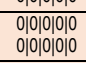 & 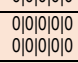 & 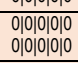 & 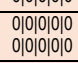 & & \\
\hline & GBIM & $\begin{array}{l}0,10101010 \\
010101010\end{array}$ & 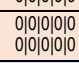 & 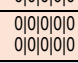 & 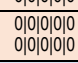 & 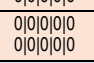 & 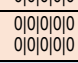 & $\begin{array}{l}0 \mid 10101010 \\
0101010100\end{array}$ & $\begin{array}{l}0 \mid 10101010 \\
0101010100\end{array}$ & 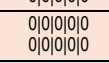 & 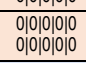 & 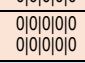 & 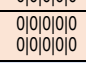 & 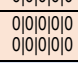 & 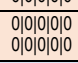 & 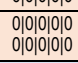 & & \\
\hline \multirow{5}{*}{ 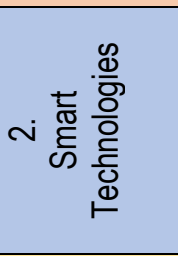 } & BChain & $\begin{array}{l}01010 \mid 010 \\
0 \mid 0101010\end{array}$ & 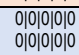 & 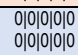 &  & $\begin{array}{l}0|0| 0|0| 0|0| 0 \\
0|0| 0|0| 0\end{array}$ &  & $\begin{array}{l}0|0| 0|0| 1 \mid 0 \\
0 \mid 1010100\end{array}$ & $\begin{array}{l}0|0| 0|0| 1 \mid 0 \\
0 \mid 1010100\end{array}$ & 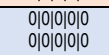 & $\begin{array}{l}010100100 \\
01010100\end{array}$ & $\begin{array}{l}010100100 \\
01010100\end{array}$ & $\begin{array}{l}010100100 \\
01010100\end{array}$ & $\begin{array}{l}0|0| 0|0| 0 \mid 0 \\
0|0| 0 \mid 100\end{array}$ & 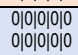 & 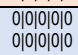 & & \\
\hline & $A I$ & 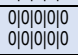 & 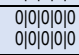 & 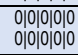 & 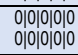 & 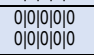 & 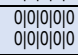 & 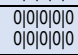 & 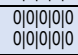 & 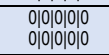 & $\begin{array}{l}0,0100100 \\
0 ; 0101010\end{array}$ & 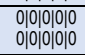 & $\begin{array}{l}010100100 \\
010101010\end{array}$ & 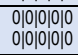 & 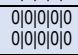 & 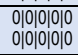 & & \\
\hline & $10 T$ & $\begin{array}{l}010101010 \\
01010010\end{array}$ & 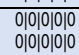 & 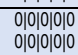 & 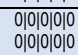 & 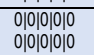 & 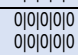 & $\begin{array}{l}0 \mid 010101010 \\
0 \mid 1010100\end{array}$ & $\begin{array}{l}0 \mid 010101010 \\
0 \mid 1010100\end{array}$ & 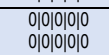 & 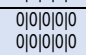 & $\begin{array}{l}0101010100 \\
01010100\end{array}$ & 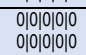 & 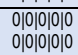 & 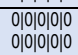 & 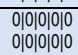 & & \\
\hline & BigData & $\begin{array}{l}0,10101010 \\
010101010\end{array}$ & 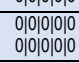 & 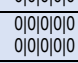 & 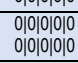 & 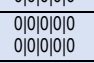 & 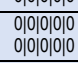 & 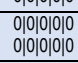 & 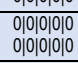 & 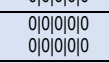 & 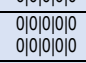 & 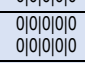 & 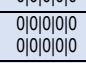 & 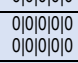 & 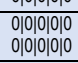 & 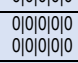 & & \\
\hline & CComp. & 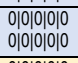 & 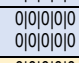 & 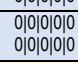 & 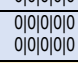 & $\begin{array}{l}0 \mid 1010101010 \\
010010100\end{array}$ & 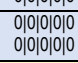 & $\begin{array}{l}0 \mid 101010100 \\
0101010100\end{array}$ & $\begin{array}{l}0 \mid 101010100 \\
0101010100\end{array}$ & 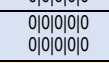 & 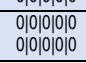 & 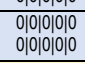 & 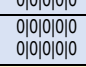 & 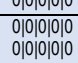 & 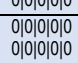 & 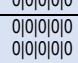 & & \\
\hline \multirow{6}{*}{ 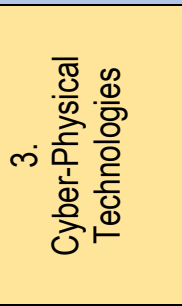 } & $A R / V R$ & $\begin{array}{l}010101010 \\
0|0| 1010 \mid 0\end{array}$ & 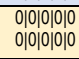 & $\begin{array}{l}0|0| 0|0| 0 \mid 10 \\
0|0| 0|0| 0 \mid 0\end{array}$ & 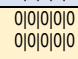 & $\begin{array}{l}0|1| 1|0| 0 \mid 0 \\
1|0| 0|0| 0\end{array}$ & 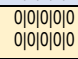 & $\begin{array}{l}0 \mid 010101010 \\
0101010100\end{array}$ & $\begin{array}{l}0 \mid 101010100 \\
0101010100\end{array}$ & 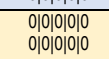 & 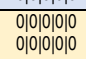 & $\begin{array}{l}0101010100 \\
01010100\end{array}$ & $\begin{array}{l}0101010100 \\
01010100\end{array}$ & $\begin{array}{l}0 \mid 010101010 \\
0 \mid 01010100\end{array}$ & $\begin{array}{l}0,010101010 \\
0,0101010\end{array}$ & $\begin{array}{l}0 \mid 010101010 \\
0 \mid 01010100\end{array}$ & & \\
\hline & Sensors & $\begin{array}{l}01010101010 \\
010101010\end{array}$ & $\begin{array}{l}01010101010 \\
010101010\end{array}$ & $\begin{array}{l}0101010 \mid 1010 \\
0 \mid 10101010\end{array}$ & $\begin{array}{l}01010101010 \\
0101010100\end{array}$ & $\begin{array}{l}0,10101010 \\
01010101010\end{array}$ & $\begin{array}{l}01010101010 \\
010101010\end{array}$ & $\begin{array}{l}01010101010 \\
0101010100\end{array}$ & $\begin{array}{l}01010101010 \\
0 \mid 10101010\end{array}$ & $\begin{array}{l}0101001000 \\
01000000\end{array}$ & $\begin{array}{l}0101001010 \\
010101010\end{array}$ & $\begin{array}{l}01010|0| 010 \\
0 \mid 1010100\end{array}$ & $\begin{array}{l}0101001010 \\
010101000\end{array}$ & $\begin{array}{l}0 \mid 010101010 \\
0 \mid 01010100\end{array}$ & $\begin{array}{l}01010101010 \\
0 \mid 0101010\end{array}$ & $\begin{array}{l}01010101010 \\
0 \mid 01010100\end{array}$ & & \\
\hline & IDloc. & $\begin{array}{l}010101010 \\
010101010\end{array}$ & 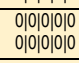 & 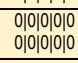 & 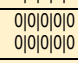 & 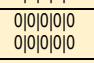 & 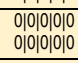 & $\begin{array}{l}0101010100 \\
0101010100\end{array}$ & 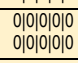 & 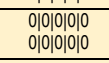 & 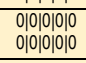 & 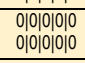 & 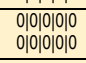 & 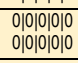 & 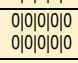 & 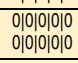 & & \\
\hline & CVison & $\begin{array}{l}01010101010 \\
010101010\end{array}$ & 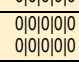 & $\begin{array}{l}0 \mid 1010101010 \\
010010100\end{array}$ & $\begin{array}{l}0 \mid 1010101010 \\
0101010100\end{array}$ & $\begin{array}{l}0 \mid 1010101010 \\
0100101010\end{array}$ & $\begin{array}{l}0 \mid 1010101010 \\
0101010100\end{array}$ & $\begin{array}{l}0 \mid 101010100 \\
0 \mid 101010100\end{array}$ & $\begin{array}{l}0 \mid 101010100 \\
0101010100\end{array}$ & 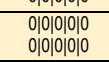 & 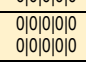 & 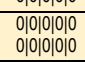 & 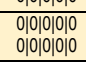 & $\begin{array}{l}0,010101010 \\
0101010100\end{array}$ & $\begin{array}{l}0,010101010 \\
010101010\end{array}$ & $\begin{array}{l}0,010101010 \\
010101010\end{array}$ & & \\
\hline & Laser & 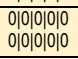 & 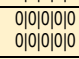 & 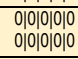 & 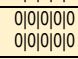 & 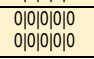 & 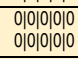 & 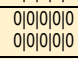 & 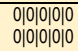 & 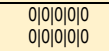 & 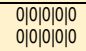 & 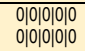 & 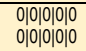 & 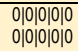 & 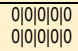 & 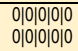 & & \\
\hline & GPR & $\begin{array}{l}010101010 \\
0 \mid 0101010\end{array}$ & 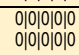 & 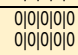 & $\begin{array}{l}0|0| 0|0| 0 \mid 10 \\
0|0| 0|0| 0 \mid 0\end{array}$ & 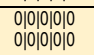 & 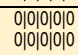 & 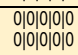 & 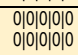 & $\begin{array}{l}010101000 \\
0,0100010\end{array}$ & $\begin{array}{l}0101010100 \\
010101010\end{array}$ & 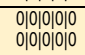 & $\begin{array}{l}0101010100 \\
010101010\end{array}$ & 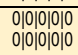 & 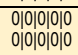 & $\begin{array}{l}0|0| 0|0| 010 \\
0|0| 0 \mid 100\end{array}$ & & \\
\hline \multirow{2}{*}{$\begin{array}{l}\text { 4. Industry } \\
\text { production }\end{array}$} & $A M$ & 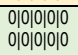 & 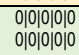 & 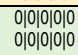 & 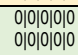 & 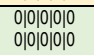 & 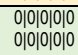 & 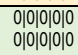 & 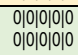 & 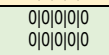 & $\begin{array}{l}0101010100 \\
010101010\end{array}$ & 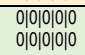 & $\begin{array}{l}010100100 \\
010101010\end{array}$ & 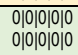 & 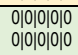 & 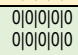 & & \\
\hline & Robotics & $\begin{array}{l}010101010 \\
010101010\end{array}$ & 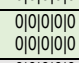 & 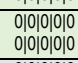 & 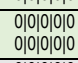 & 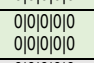 & 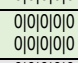 & 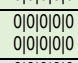 & 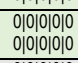 & 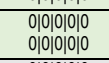 & 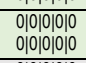 & 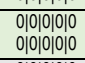 & 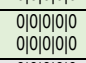 & 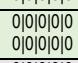 & 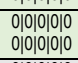 & 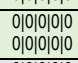 & & \\
\hline \multirow{4}{*}{ 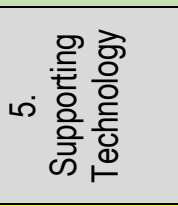 } & CT/IT & $\begin{array}{l}010101010 \\
010101010\end{array}$ & 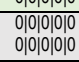 & $\begin{array}{l}0 \mid 101010100 \\
0101010100\end{array}$ & $\begin{array}{l}01010101010 \\
0101010100\end{array}$ & $\begin{array}{l}0 \mid 1010101010 \\
01010101010\end{array}$ & $\begin{array}{l}0101010100 \\
0101010100\end{array}$ & $\begin{array}{l}0101010100 \\
0101010100\end{array}$ & $\begin{array}{l}0101010100 \\
0101010100\end{array}$ & 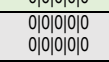 & 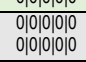 & 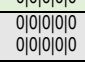 & 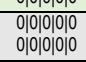 & 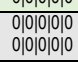 & 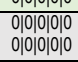 & 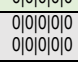 & & \\
\hline & Sweb & $\begin{array}{l}010101010 \\
0 \mid 0101010\end{array}$ & 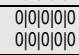 & $\begin{array}{l}0|0| 0|0| 0 \mid 10 \\
0|0| 0|0| 0 \mid 0\end{array}$ & 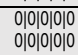 & $\begin{array}{l}0|0| 0|0| 0|0| 0 \\
0|0| 0|0| 0 \mid 0\end{array}$ & 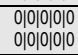 & 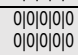 & 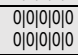 & $\begin{array}{l}010101000 \\
0,0100010\end{array}$ & $\begin{array}{l}0101010100 \\
01010100\end{array}$ & 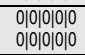 & $\begin{array}{l}0101010100 \\
010101010\end{array}$ & $\begin{array}{l}0|0| 0|0| 010 \\
0|0| 0 \mid 100\end{array}$ & 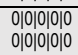 & 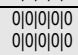 & & \\
\hline & UAVs & $\begin{array}{l}010101010 \\
0 \mid 10101010\end{array}$ &  &  & 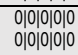 & 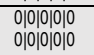 & 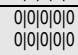 & 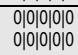 & 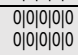 & 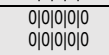 & $\begin{array}{l}0101010100 \\
010101010\end{array}$ &  & $\begin{array}{l}0101010100 \\
010101010\end{array}$ & 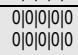 & 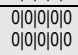 & 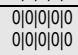 & & \\
\hline & mobile & $\begin{array}{l}0,10101010 \\
010101010\end{array}$ & 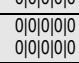 & 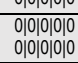 & 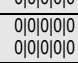 & 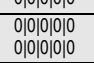 & 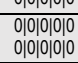 & 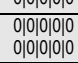 & 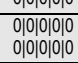 & 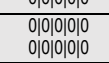 & 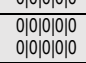 & 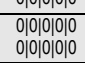 & 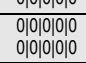 & 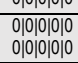 & 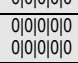 & 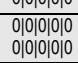 & & \\
\hline \multicolumn{2}{|c|}{ Total numbers (summation) } & & & & & & & & & & & & & & & & & \\
\hline
\end{tabular}




\begin{tabular}{|c|c|c|c|c|c|c|c|c|c|c|c|c|c|c|c|c|c|}
\hline \multirow{2}{*}{\multicolumn{2}{|c|}{$\begin{array}{l}\text { XXX Context } \\
\text { Eng. Method-oriented } \\
\text { Framework (Building) }\end{array}$}} & \multicolumn{5}{|c|}{ Industrial Design Process } & \multicolumn{5}{|c|}{$\begin{array}{c}\text { Manufacturing / } \\
\text { Prefabrication Process }\end{array}$} & \multicolumn{5}{|c|}{$\begin{array}{c}\text { Assembly / } \\
\text { Pre-installation Process }\end{array}$} & \multirow[b]{3}{*}{ 产 } \\
\hline & & NDf & Df1x & Df2x & Df3x & $\mathrm{Df} 4 \mathrm{x}$ & M1 & M2 & M3 & M4 & M5 & A1 & A2 & A3 & A4 & A5 & \\
\hline 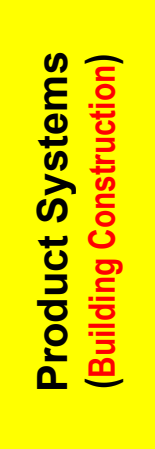 & 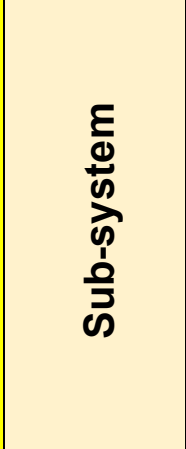 & 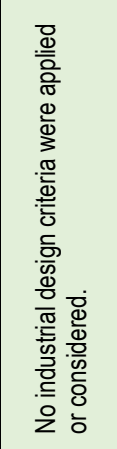 & 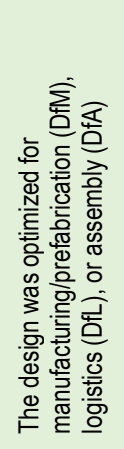 & 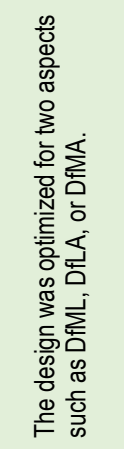 & 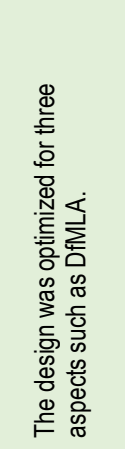 & 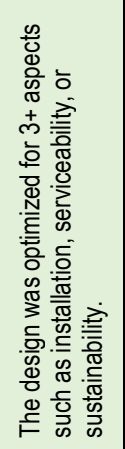 & 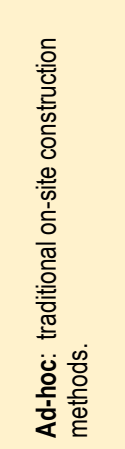 & 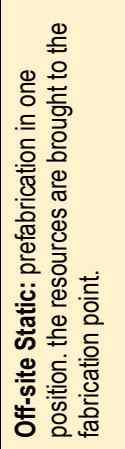 & 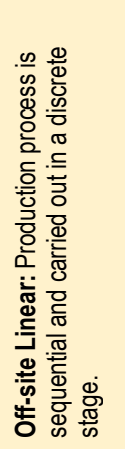 & 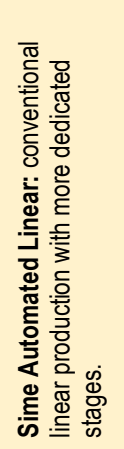 &  & 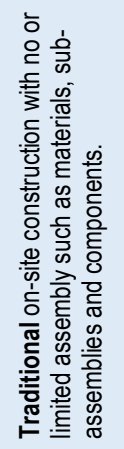 & 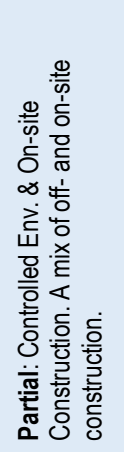 & 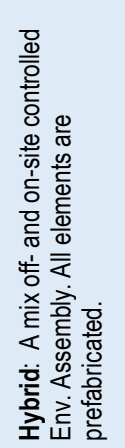 & 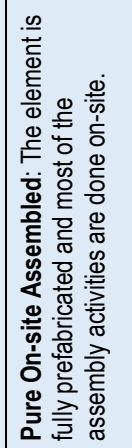 & 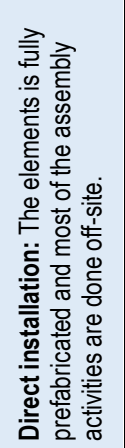 & \\
\hline \multirow{5}{*}{ 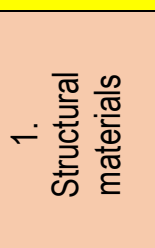 } & Precast & $0|0| 0|0| 0$ & $0|0| 0|0| 0$ & $0|0| 0|0| 0$ & $0|0| 0|0| 0$ & $0|0| 0|0| 0$ & $0|0| 0|0| 0$ & $0|0| 0|0| 0$ & $0|0| 0|0| 0$ & $0|0| 0|0| 0$ & $0|0| 0|0| 0$ & $0|0| 0|0| 0$ & $0|0| 0|0| 0$ & $0|0| 0|0| 0$ & $0|0| 0|0| 0$ & $0|0| 0|0| 0$ & \\
\hline & Streel & $0|0| 0|0| 0$ & $0|0| 0|0| 0$ & $0|0| 0|0| 0$ & $0|0| 0|0| 0$ & $0|0| 0|0| 0$ & $0|0| 0|0| 0$ & $0|0| 0|0| 0$ & $0|0| 0|0| 0$ & $0|0| 0|0| 0$ & $0|0| 0|0| 0$ & $0|0| 0|0| 0$ & $0|0| 0|0| 0$ & $0|0| 0|0| 0$ & $0|0| 0|0| 0$ & $0|0| 0|0| 0$ & \\
\hline & Timber & $0|0| 0|0| 0$ & $0|0| 0|0| 0$ & $0|0| 0|0| 0$ & $0|0| 0|0| 0$ & $0|0| 0|0| 0$ & $0|0| 0|0| 0$ & $0|0| 0|0| 0$ & $0|0| 0|0| 0$ & $0|0| 0|0| 0$ & $0|0| 0|0| 0$ & $0|0| 0|0| 0$ & $0|0| 0|0| 0$ & $0|0| 0|0| 0$ & $0|0| 0|0| 0$ & $0|0| 0|0| 0$ & \\
\hline & Polymer & $0|0| 0|0| 0$ & $0|0| 0|0| 0$ & $0|0| 0|0| 0$ & $0|0| 0|0| 0$ & $0|0| 0|0| 0$ & \begin{tabular}{|l|}
$0|0| 0|0| 0$ \\
\end{tabular} & $0|0| 0|0| 0$ & $0|0| 0|0| 0 \mid 0$ & $0|0| 0|0| 0$ & $0|0| 0|0| 0$ & \begin{tabular}{|l|}
$0|0| 0|0| 0$ \\
\end{tabular} & $0|0| 0|0| 0$ & $0|0| 0|0| 0$ & $0|0| 0|0| 0$ & $0|0| 0|0| 0$ & \\
\hline & Composite & $0|0| 0|0| 0$ & $0|0| 0|1| 0$ & $0|0| 0|0| 0$ & $0|0| 0|0| 0$ & $0|0| 0|0| 0 \mid 0$ & $0|0| 0|0| 0$ & $0|0| 0 \mid 110$ & $0|0| 0|0| 0 \mid 0$ & $0|0| 0|0| 0$ & $0|0| 0|0| 0 \mid 0$ & $0|0| 0|1| 0$ & $0|0| 0|0| 0$ & $0|0| 0|0| 0$ & $0|0| 0|0| 0$ & $0|0| 0|0| 0 \mid 0$ & \\
\hline \multirow{4}{*}{ 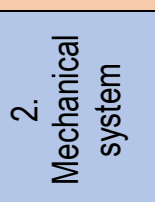 } & HVAC & $1|0| 0|0| 0$ & $0|0| 0|0| 0$ & $0|0| 0|0| 0$ & $0|0| 0|0| 0$ & $0|0| 0|0| 0 \mid 0$ & $1|0| 0|0| 0 \mid 0$ & $0|0| 0|0| 0$ & $0|0| 0|0| 0$ & $0|0| 0|0| 0$ & $0|0| 0|0| 0$ & $1|0| 0|0| 0$ & $0|0| 0|0| 0$ & $0|0| 0|0| 0$ & $0|0| 0|0| 0$ & $0|0| 0|0| 0$ & \\
\hline & Plumbing & $1 / 0|0| 0 \mid 0$ & $0|0| 0|0| 0$ & $0|0| 0|0| 0$ & $0|0| 0|0| 0$ & $0|0| 0|0| 0$ & $1|0| 0|0| 0$ & $0|0| 0|0| 0$ & $0|0| 0|0| 0$ & $0|0| 0|0| 0$ & $0|0| 0|0| 0$ & $1|0| 0|0| 0$ & $0|0| 0|0| 0$ & $0|0| 0|0| 0$ & $0|0| 0|0| 0$ & $0|0| 0|0| 0$ & \\
\hline & & $|0| 0|0| 0 \mid 0$ & $0|0| 0|0| 0$ & $0|0| 0|0| 0$ & $0|0| 0|0| 0$ & $0|0| 0|0| 0$ & 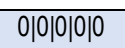 & $0|0| 0|0| 0$ & 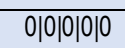 & $0|0| 0|0| 0$ & $0|0| 0|0| 0 \mid 0$ & 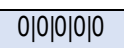 & $0|0| 0|0| 0$ & $0|0| 0|0| 0$ & $0|0| 0|0| 0 \mid 0$ & $0|0| 0|0| 0$ & \\
\hline & & $0|0| 0|0| 0$ & $0|0| 0|0| 0$ & $0|0| 0|0| 0$ & $0|0| 0|0| 0$ & $0|0| 0|0| 0$ & $0|0| 0|0| 0$ & $0|0| 0|0| 0$ & $0|0| 0|0| 0$ & $0|0| 0|0| 0$ & $0|0| 0|0| 0$ & $0|0| 0|0| 0$ & $0|0| 0|0| 0$ & $0|0| 0|0| 0$ & $0|0| 0|0| 0$ & $0|0| 0|0| 0$ & \\
\hline \multirow{4}{*}{ m. } & \begin{tabular}{|l} 
Electricity \\
\end{tabular} & $1|0| 0|0| 0$ & $0|0| 0|0| 0$ & $0|0| 0|0| 0$ & $0|0| 0|0| 0$ & $0|0| 0|0| 0$ & $1|0| 0|0| 0$ & $0|0| 0|0| 0$ & $0|0| 0|0| 0$ & $0|0| 0|0| 0 \mid 0$ & $0|0| 0|0| 0$ & $1|0| 0|0| 0$ & $0|0| 0|0| 0$ & $0|0| 0|0| 0$ & $0|0| 0|0| 0$ & $0|0| 0|0| 0$ & \\
\hline & Phone & $1|0| 0|0| 0$ & $0|0| 0|0| 0 \mid 0$ & $0|0| 0|0| 0 \mid 0$ & $0|0| 0|0| 0 \mid 0$ & 0 & $11|0| 0|0| 0$ & $0|0| 0|0| 0$ & $0|0| 0|0| 0 \mid 0$ & $00|0| 0|0| 0 \mid 0$ & $0|0| 0|0| 0 \mid 0$ & $11|0| 0|0| 0$ & $0|0| 0|0| 0 \mid 0$ & $0|0| 0|0| 0$ & $0|0| 0|0| 0$ & $0|0| 0|0| 0 \mid 0$ & \\
\hline & \begin{tabular}{|l|} 
Internet \\
\end{tabular} & $1|0| 0|0| 0$ & $0|0| 0|0| 0$ & $0|0| 0|0| 0$ & $0|0| 0|0| 0$ & $0|0| 0|0| 0$ & $1|0| 0|0| 0 \mid 0$ & $0|0| 0|0| 0$ & $0|0| 0|0| 0$ & $0|0| 0|0| 0$ & $0|0| 0|0| 0$ & $1|0| 0|0| 0$ & $0|0| 0|0| 0$ & $0|0| 0|0| 0$ & $0|0| 0|0| 0$ & $0|0| 0|0| 0 \mid 0$ & \\
\hline & \begin{tabular}{|l}
$T V$ Cable \\
\end{tabular} & $1 /|0| 0|0| 0$ & $0|0| 0|0| 0$ & $0|0| 0|0| 0$ & $0|0| 0|0| 0$ & $0|0| 0|0| 0 \mid 0$ & $1|0| 0|0| 0 \mid 0$ & $0|0| 0|0| 0$ & $0|0| 0|0| 0 \mid 0$ & $0|0| 0|0| 0$ & $0|0| 0|0| 0 \mid 0$ & $1|0| 0|0| 0$ & $0|0| 0|0| 0$ & $0|0| 0|0| 0$ & $0|0| 0|0| 0$ & $0|0| 0|0| 0 \mid 0$ & \\
\hline \multirow{3}{*}{ ナ悹离 } & Interior & $0|0| 0|0| 0$ & $0|0| 0|1| 0$ & $0|0| 0|0| 0$ & $0|0| 0|0| 0$ & $0|0| 0|0| 0$ & \begin{tabular}{|l|}
$0|0| 0|0| 0$ \\
\end{tabular} & $0|0| 0|1| 10$ & \begin{tabular}{|l|}
$0|0| 0|0| 0$ \\
\end{tabular} & $0|0| 0|0| 0$ & $0|0| 0|0| 0$ & $0|0| 0|1| 0$ & $0|0| 0|0| 0$ & $0|0| 0|0| 0$ & $0|0| 0|0| 0$ & $0|0| 0|0| 0$ & \\
\hline & \begin{tabular}{|l} 
Exterior \\
\end{tabular} & $0|0| 0|0| 0$ & $0|0| 0|1| 0$ & $0|0| 0|0| 0$ & $0|0| 0|0| 0$ & $0|0| 0|0| 0$ & $0|0| 0|0| 0$ & $0|0| 0|1| 10$ & $0|0| 0|0| 0 \mid 0$ & $0|0| 0|0| 0$ & $0|0| 0|0| 0$ & $0|0| 0|1| 0$ & $0|0| 0|0| 0$ & $0|0| 0|0| 0$ & $0|0| 0|0| 0$ & $0|0| 0|0| 0$ & \\
\hline & & $0|0| 0|0| 0$ & $0|0| 0|0| 0$ & $0|0| 0|0| 0$ & $0|0| 0|0| 0$ & $0|0| 0|0| 0 \mid 0$ & $0|0| 0|0| 0$ & $0|0| 0|0| 0$ & $0|0| 0|0| 0 \mid 0$ & $0|0| 0|0| 0 \mid 0$ & $0|0| 0|0| 0$ & $0|0| 0|0| 0 \mid 0$ & $0|0| 0|0| 0 \mid 0$ & $0|0| 0|0| 0$ & $0|0| 0|0| 0$ & $0|0| 0|0| 0$ & \\
\hline \multirow{4}{*}{ 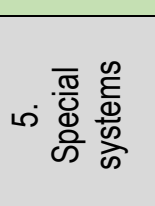 } & & $0|0| 0|0| 0$ & $0|0| 0|0| 0$ & $0|0| 0|0| 0$ & $0|0| 0|0| 0$ & $0|0| 0|0| 0$ & $0|0| 0|0| 0$ & $0|0| 0|0| 0$ & $0|0| 0|0| 0$ & $0|0| 0|0| 0 \mid 0$ & $0|0| 0|0| 0$ & $0|0| 0|0| 0$ & $0|0| 0|0| 0 \mid 0$ & $0|0| 0|0| 0$ & $0|0| 0|0| 0$ & $0|0| 0|0| 0$ & \\
\hline & & $0|0| 0|0| 0 \mid 0$ & $0|0| 0|0| 0$ & $0|0| 0|0| 0$ & $0|0| 0|0| 0$ & $0|0| 0|0| 0 \mid 0$ & $0|0| 0|0| 0$ & $0|0| 0|0| 0$ & $0|0| 0|0| 0 \mid 0$ & $0|0| 0|0| 0 \mid 0$ & $0|0| 0|0| 0$ & $0|0| 0|0| 0 \mid 0$ & $0|0| 0|0| 0$ & $0|0| 0|0| 0$ & $0|0| 0|0| 0$ & $0|0| 0|0| 0 \mid 0$ & \\
\hline & & $0|0| 0|0| 0$ & $0|0| 0|0| 0$ & $0|0| 0|0| 0$ & $0|0| 0|0| 0$ & $0|0| 0|0| 0$ & 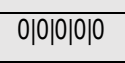 & $0|0| 0|0| 0$ & 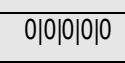 & $0|0| 0|0| 0$ & $0|0| 0|0| 0$ & $0|0| 0|0| 0 \mid 0$ & $0|0| 0|0| 0$ & $0|0| 0|0| 0$ & $0|0| 0|0| 0$ & $0|0| 0|0| 0$ & \\
\hline & & $0|0| 0|0| 0$ & $0|0| 0|0| 0$ & $0|0| 0|0| 0$ & $0|0| 0|0| 0$ & $0|0| 0|0| 0 \mid 0$ & $0|0| 0|0| 0$ & $0|0| 0|0| 0$ & $0|0| 0|0| 0$ & $0|0| 0|0| 0$ & $0|0| 0|0| 0$ & $0|0| 0|0| 0$ & $0|0| 0|0| 0$ & $0|0| 0|0| 0$ & $0|0| 0|0| 0$ & $0|0| 0|0| 0$ & \\
\hline Total num & summation) & & & & & & & & & & & & & & & & \\
\hline
\end{tabular}




\begin{tabular}{|c|c|c|c|c|c|c|c|c|c|c|c|c|c|c|c|c|c|}
\hline \multirow{2}{*}{\multicolumn{2}{|c|}{$\begin{array}{l}\text { XXX Context } \\
\text { Eng. Method-oriented } \\
\text { Framework (non-Building) }\end{array}$}} & \multicolumn{5}{|c|}{ Industrial Design Process } & \multicolumn{5}{|c|}{$\begin{array}{c}\text { Manufacturing / } \\
\text { Prefabrication Process }\end{array}$} & \multicolumn{5}{|c|}{$\begin{array}{c}\text { Assembly / } \\
\text { Pre-installation Process }\end{array}$} & \multirow[b]{3}{*}{ 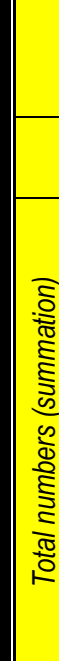 } \\
\hline & & NDF & DF1x & DF2x & DF3x & DF4x & M1 & M2 & M3 & M4 & M5 & A1 & A2 & A3 & A4 & A5 & \\
\hline 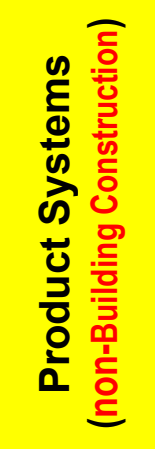 & 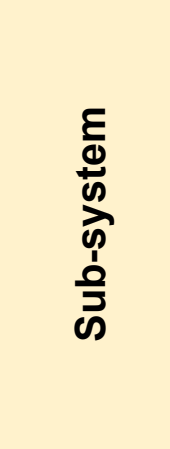 & 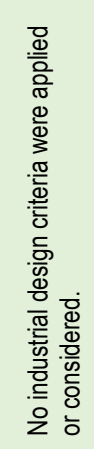 & 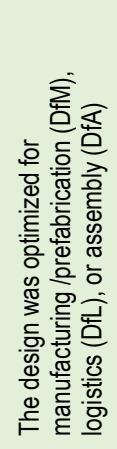 & 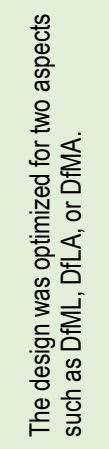 & 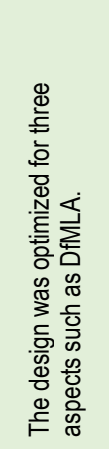 & 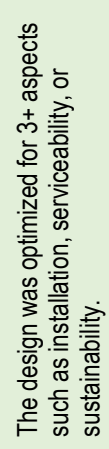 & 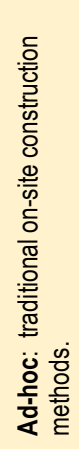 & 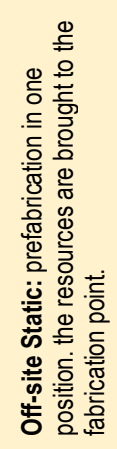 & 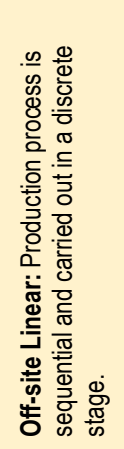 & 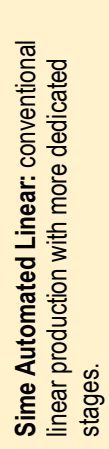 & 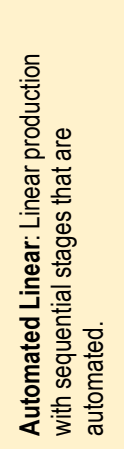 & 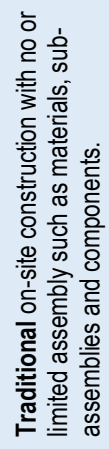 & 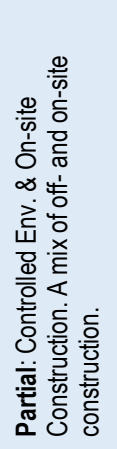 & 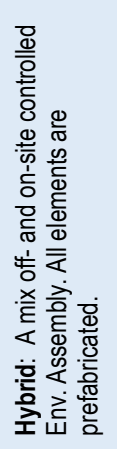 & 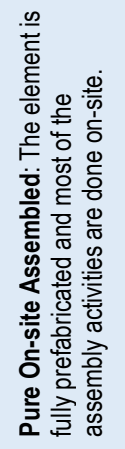 & 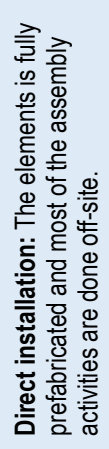 & \\
\hline \multirow{5}{*}{ 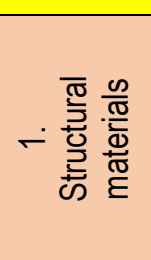 } & Precast & $0|0| 0$ & $0|0| 0$ & $0|0| 0$ & $0|0| 0$ & $0|0| 0$ & $010 / 0$ & $0|0| 0$ & $0|0| 0$ & $0|0| 0$ & $0|0| 0$ & $0|0| 0$ & $0|0| 0$ & $0|0| 0$ & $0|0| 0$ & $0|0| 0$ & \\
\hline & Streel & $0|0| 0$ & $0|0| 0$ & $0|0| 0$ & $0|0| 0$ & $0|0| 0$ & $0|0| 0$ & $0|0| 0$ & $0 \mid 010$ & $0|0| 0$ & $0 \mid 010$ & $0|0| 0$ & $0|0| 0$ & $0|0| 0$ & $0|0| 0$ & $0|0| 0$ & \\
\hline & Asphalt & $0|0| 0$ & $0|0| 0$ & $0|0| 0$ & $0|0| 0$ & $0|0| 0$ & 01010 & $0|0| 0$ & $0|0| 0$ & $0|0| 0$ & $0|0| 0$ & $0|0| 0$ & $0|0| 0$ & $0|0| 0$ & $0 \mid 010$ & $0|0| 0$ & \\
\hline & Polymer & $0|0| 0$ & $0|0| 0$ & $0|0| 0$ & $0|0| 0$ & $0|0| 0$ & 01010 & $0|0| 0$ & $0|0| 0$ & $0|0| 0$ & $0|0| 0$ & $0|0| 0$ & $0 \mid 010$ & $0 \mid 010$ & $0|0| 0$ & $0|0| 0$ & \\
\hline & Composite & 01010 & $0 \mid 010$ & $0|0| 0$ & $0|0| 0$ & $0 \mid 010$ & 01010 & $0 \mid 010$ & 01010 & $0|0| 0$ & 01010 & $0|0| 0$ & $0 \mid 010$ & $0 \mid 010$ & 01010 & $0|0| 0$ & \\
\hline \multirow{3}{*}{$\sim<\frac{\frac{\varepsilon}{\Phi}}{\frac{\omega}{\omega}}$} & & 01010 & $0|0| 0$ & $0|0| 0$ & 01010 & 01010 & 01010 & 01010 & 01010 & $0|0| 0$ & 01010 & $0|0| 0$ & 01010 & 01010 & 01010 & $0 \mid 010$ & \\
\hline & & $0 \mid 010$ & $0|0| 0$ & $0|0| 0$ & $0|0| 0$ & $0 \mid 010$ & 01010 & $0|0| 0$ & $0|0| 0$ & $0|0| 0$ & $0 \mid 010$ & $0|0| 0$ & $0|0| 0$ & $0 \mid 010$ & $0 \mid 010$ & $0|0| 0$ & \\
\hline & & 01010 & $0|0| 0$ & $0|0| 0$ & $0 \mid 010$ & $0 \mid 010$ & 01010 & $0 \mid 010$ & $0 \mid 010$ & $0|0| 0$ & 01010 & $0|0| 0$ & $0 \mid 010$ & 01010 & $0 \mid 010$ & $0|0| 0$ & \\
\hline \multirow{4}{*}{$\dot{m} \frac{\frac{E}{\mathcal{D}}}{\frac{\omega}{\omega}}$} & & $0|0| 0$ & $0|0| 0$ & $0|0| 0$ & $0|0| 0$ & $0|0| 0$ & 01010 & $0|0| 0$ & $0|0| 0$ & $0|0| 0$ & $0 \mid 010$ & $0|0| 0$ & $0|0| 0$ & $0 \mid 010$ & $0|0| 0$ & $0|0| 0$ & \\
\hline & & 01010 & $0|0| 0$ & $0|0| 0$ & $0|0| 0$ & $0|0| 0$ & 01010 & $0|0| 0$ & 01010 & $0|0| 0$ & $0 \mid 010$ & $0|0| 0$ & $0 \mid 010$ & $0 \mid 010$ & $0 \mid 010$ & $0|0| 0$ & \\
\hline & & $0 \mid 010$ & $0|0| 0$ & $0|0| 0$ & $0|0| 0$ & $0 \mid 010$ & 01010 & $0|0| 0$ & $0|0| 0$ & $0|0| 0$ & $0|0| 0$ & $0|0| 0$ & 01010 & $0 \mid 010$ & $0|0| 0$ & $0|0| 0$ & \\
\hline & & 01010 & $0 \mid 010$ & $0|0| 0$ & $0 \mid 010$ & $0 \mid 010$ & 01010 & $0|0| 0$ & 01010 & $0|0| 0$ & 01010 & $0|0| 0$ & 01010 & 01010 & 01010 & $0|0| 0$ & \\
\hline \multirow{3}{*}{ ナல } & & $0 \mid 010$ & $0|0| 0$ & $0|0| 0$ & $0|0| 0$ & $0|0| 0$ & 01010 & $0|0| 0$ & 01010 & $0|0| 0$ & 01010 & $0|0| 0$ & 01010 & 01010 & 01010 & $0|0| 0$ & \\
\hline & & 01010 & $0|0| 0$ & $0|0| 0$ & $0|0| 0$ & $0|0| 0$ & 01010 & $0|0| 0$ & $0 \mid 010$ & $0|0| 0$ & 01010 & $0|0| 0$ & 01010 & 01010 & $0 \mid 010$ & 01010 & \\
\hline & & 01010 & $0|0| 0$ & $0|0| 0$ & $0|0| 0$ & $0|0| 0$ & 01010 & 01010 & $0|0| 0$ & 01010 & $0 \mid 010$ & $0|0| 0$ & $0|0| 0$ & 01010 & $0 \mid 010$ & 01010 & \\
\hline \multirow{4}{*}{ ம } & & $0 \mid 010$ & $0 \mid 010$ & $0|0| 0$ & 01010 & $0|0| 0$ & 01010 & $0|0| 0$ & 01010 & 01010 & $0 \mid 010$ & $0|0| 0$ & $0|0| 0$ & $0 \mid 010$ & 01010 & $0|0| 0$ & \\
\hline & & 01010 & $0|0| 0$ & $0|0| 0$ & 01010 & $0|0| 0$ & 01010 & $0|0| 0$ & $0 \mid 010$ & $0|0| 0$ & 01010 & $0|0| 0$ & 01010 & 01010 & 01010 & $0|0| 0$ & \\
\hline & & $0 \mid 010$ & $0|0| 0$ & $0|0| 0$ & $0 \mid 010$ & $0 \mid 010$ & 01010 & $0 \mid 010$ & $0|0| 0$ & $0|0| 0$ & 01010 & $0|0| 0$ & $0|0| 0$ & $0 \mid 010$ & 01010 & $0|0| 0$ & \\
\hline & & $0 \mid 010$ & $0|0| 0$ & $0|0| 0$ & $0|0| 0$ & $0|0| 0$ & 01010 & $0|0| 0$ & 01010 & $0|0| 0$ & 01010 & $0|0| 0$ & $0|0| 0$ & $0 \mid 100$ & $0|0| 0$ & $0|0| 0$ & \\
\hline \multicolumn{2}{|c|}{ Total numbers (summation) } & & & & & & & & & & & & & & & & \\
\hline
\end{tabular}

